\title{
Why and How the Supreme Court Should End the Death Penalty
}

\author{
By Kenneth Williams*
}

\section{Introduction}

IN A RECENT OPINION dissenting from the Court's holding that a certain drug used in Oklahoma and other states to carry out lethal injections was constitutional, Justice Breyer called for full briefing on the issue of the constitutionality of the death penalty itself. ${ }^{1}$ The decades-long litigation over the constitutionality of execution methods obscured many of the important issues associated with the death penalty. Now that the Supreme Court has brought an end to this litigation, this is an appropriate time to have an honest conversation about whether the United States should continue to employ the death penalty. The time is now ripe to have this conversation because of the declining public support for the death penalty and the difficulty the courts have had in administering it. The purpose of this article is to contribute to the conversation about the constitutionality of the death penalty.

This article will begin with a discussion of the declining public support for the death penalty and some of the reasons behind the decline in Part I. Part II pertains to how the legislature and the Supreme Court have attempted to rectify the problems that have plagued the death penalty and why these attempts have largely failed. Given the difficulties the Supreme Court has encountered in trying to fix the death penalty, Part II also assesses the available options moving forward: either continue the attempt to reform and regulate the death penalty or abolish it. The article concludes that abolition is the best option moving forward. Part II, lastly, lays out the doctrinal framework that the Supreme Court has created that would enable the Court to abolish the death penalty. Finally, Part III lists some of the anticipated

* Professor of Law, South Texas College of Law Houston. In addition, federal habeas attorney for several Texas death row inmates.

1. See Glossip v. Gross, 135 S. Ct. 2716, 2755 (2015) (Breyer, J., dissenting). 
objections to the Court abolishing the death penalty, the Court's previous failed attempt to do so, and why abolition is likely to achieve greater public acceptance this time.

\section{Declining Public Support}

Public support for the death penalty has drastically declined during the last twenty years. According to a Gallup survey, in 1994, 80\% of Americans supported the death penalty. ${ }^{2}$ In 2014, support for the death penalty was at $60 \% .^{3}$ There are other strong indicia of the public's declining support for the ultimate punishment. First, the number of individuals sentenced to death by juries and judges has also declined significantly during the past twenty years. In 1994, 311 death sentences were meted out by juries and judges. ${ }^{4}$ In 2014 , only seventythree death sentences were imposed. ${ }^{5}$ In 2015 , forty-nine individuals received death sentences, a $33 \%$ decline from the previous year and the fewest since $1973 .{ }^{6}$ Even in Texas, the leader among the states in carrying out the death penalty since 1976, far fewer death sentences are being imposed. ${ }^{7}$ Juries sentenced forty-eight individuals to death in 1999, but only eleven individuals in 2014 and an astoundingly low total of two individuals in 2015. ${ }^{8}$

Second, there has been a steady, nationwide decline in executions in the last twenty years. Executions have fallen from a high of ninety-eight executions in 1999, to thirty-five in 2014, and twenty-eight

2. See Jeffrey M. Jones, Americans' Support for Death Penalty Stable, Gallup (Oct. 23, 2014), http://www.gallup.com/poll/178790/americans-support-death-penalty-stable.aspx? utm_source $=$ death $\% 20$ penalty\&utm_medium $=$ search\&utm_campaign=tiles $\quad[$ https: $/ /$ per ma.cc/QH9T-KFZ8]; see also, Baxter Oliphant, Support for death penalty lowest in more than four decades, Pew Research Ctr. (Sep. 29, 2016), http://www.pewresearch.org/fact-tank/ 2016/09/29/support-for-death-penalty-lowest-in-more-than-four-decades/ [https://perma .cc/2L7Q-V7A5] (reporting poll results finding that $49 \%$ of public supported the death penalty while $42 \%$ were opposed).

3. See Jones, supra note 2.

4. Death Sentences in the United States From 1977 By State and By Year, Death Penalty INFO. CTR., http://www.deathpenaltyinfo.org/death-sentences-united-states-1977-2008, (last visited Dec. 15, 2016) [https://perma.cc/CC5W-VNE3] [hereinafter By Year, DeATH Penalty Info. CTrR.].

5. Id.

6. Timothy Williams, Executions by States Fell in 2015, Report Says, N.Y. Times, (Dec. 16, 2015), http:/ /www.nytimes.com/2015/12/16/us/executions-by-states-fell-in-2015-reportsays.htmlhpw\&rref=us\&action=click\&pgtype $=$ Homepage\&module=well-region\&region=bot tom-well\&WT.nav=bottom-well\&_r=0 [https://perma.cc/M5XS-MRBC].

7. By Year, Death Penalty Info. Ctr., supra note 4.

8. Id. 
in 2015, the lowest number of executions since 1991.9 Third, during the last twenty years, Connecticut, Illinois, Maryland, New Jersey, New Mexico, and New York have abolished the death penalty and the Governors of four other states have imposed moratoriums. ${ }^{10}$ Finally, fewer Americans believe the death penalty to be morally acceptable. Gallup began to measure public sentiment regarding the morality of the death penalty in 2001. The number of Americans who believe the death penalty to be morally acceptable during this time period has gone from a high of $71 \%$ in 2006 down to $60 \%$ in 2014. ${ }^{11}$ Most surprisingly, this decline in public support for the death penalty has occurred despite the public's rising anxiety over terrorism. ${ }^{12}$

As discussed below, there are many reasons for the decline in the public's confidence in the death penalty.

\section{A. Innocence}

No issue has had a bigger impact on the public's attitude towards the death penalty than the possibility of an innocent person being executed. Since 1973, there have been approximately 156 actual exonerations of death row inmates. ${ }^{13}$ There are currently approximately 3,000 individuals on death rows throughout the United States. ${ }^{14}$ Researchers estimate that about $4 \%$ of those sentenced to death are actu-

9. Facts About the Death Penalty, Death Penalty Info. Ctr., http://www.deathpenaltyinfo.org/documents/FactSheet.pdf (last visited Dec. 15, 2016) [https://perma.cc/NLY3C7DW] [hereinafter Facts, Death Penalty Info. Ctr.].

10. States With and Without the Death Penalty, Death Penalty Info. Ctr., http://www .deathpenaltyinfo.org/states-and-without-death-penalty (last visited Dec. 15, 2016) [https:/ /perma.cc/5ZQ2-9DPT] [hereinafter States, DeATh Penalty Info. CTr.]. However, California voters did vote to retain its death penalty in the November 2016 elections. See Mike McPhate, California Today: Why Californians Kept the Death Penalty, N.Y. Times (Nov. 11, 2016), http://www.nytimes.com/2016/11/11/us/california-today-death-penalty-vote.html ?_r=0 [https://perma.cc/U9TZ-98XY].

11. See Art Swift, Most Americans Continue to Say Death Penalty Morally Ok, Gallup (June 4, 2015), http://www.gallup.com/poll/183503/americans-continue-say-death-penalty-morally.aspx?utm_source=\&utm_medium $=\& u t m \_c a m p a i g n=t i l e s \quad[\mathrm{https}: / /$ perma.cc $/ 59 \mathrm{Q} 7-\mathrm{FU}$ QF].

12. See, e.g., Rebecca Riffkin, Americans Name Terrorism as No. 1 U.S. Problem, Gallup (Dec. 14, 2015) http://www.gallup.com/poll/187655/americans-name-terrorism-no-problem.aspx [https://perma.cc/B6QY-CWZW].

13. Innocence: List of Those Freed From Death Row, Death Penalty Info Ctr., http://www .deathpenaltyinfo.org/innocence-list-those-freed-death-row (last visited Oct. 27, 2016) [https://perma.cc/Y7JS-UH4C].

14. Deborah Fins, Death Row U.S.A., NAACP Legal Defense Fund, Inc. (Apr. 1, 2015), http://www.deathpenaltyinfo.org/documents/DRUSASpring2015.pdf [https://perma.cc/ UC5Q-NZ59]. 
ally innocent, ${ }^{15}$ which would mean that there are currently about 120 individuals on death row who may be executed for crimes that they did not commit. Unfortunately, not every death row inmate with strong innocence claims has been exonerated. There have been credible reports indicating that there is a strong possibility that innocent individuals have been executed. ${ }^{16}$ One such individual is Cameron Todd Willingham, who was convicted and sentenced to death as a result of a fire that killed his three young daughters. ${ }^{17}$ The state's case against Willingham consisted primarily of an expert's conclusion that the fire was deliberately set and that because he was the only adult in the home at the time of the fire, Willingham deliberately started the fire. ${ }^{18}$ Shortly before Willingham's scheduled execution, a report by an acclaimed scientist and fire investigator indicated that the fire that killed Willingham's three daughters was not deliberately set, but was accidental. ${ }^{19}$ This information failed to convince either the Texas governor or the Board of Pardons and Parole to grant clemency-or even delay Willingham's execution-and he was put to death. ${ }^{20}$ Since Willingham's execution, additional fire investigators have reviewed the case and have determined that the methods used by the state's trial expert were flawed and that the fire was not the result of arson. ${ }^{21}$ Nothing can be done to rectify what appears to have been the wrongful execution of Willingham and others. Cases like Willingham's, combined with the irrevocability of the death penalty and the other problems that plague the death penalty that are discussed later in this

15. Glossip v. Gross, 576 U.S. 2726, 2758 (2015) (Breyer, J., dissenting).

16. See e.g., James S. Liebman, You Can't Fix the Death Penalty: Carlos DeLuna's Execution Shows That a Faster, Cheaper Death Penalty is a Dangerous Idea, L.A. Times (June 1, 2012), http:/ /articles.latimes.com/2012/jun/01/opinion/la-oe-liebman-death-penalty-deluna20120601 [https://perma.cc/6CGF-4XLG] (after a thorough investigation, the authors concluded that Carlos DeLuna was sentenced to death and executed for a crime that he did not commit); Press Release, Gov. Ritter Grants Posthumous Pardon in Case Dating Back to 1930s, Jan. 7, 2011), http://www.deathpenaltyinfo.org/documents/ArridyPardon.pdf [https://perma.cc/5GXS-5C9M] (discussing the Colorado Governor's decision to grant a posthumous pardon because, according to the Governor, "an overwhelming body of evidence indicates the 23-year-old was innocent, including false and coerced confessions, the likelihood that Arridy was not in Pueblo at the time of the killing, and an admission of guilt by someone else.").

17. See David Gran, Trial by Fire, Did Texas Execute an Innocent Man?, The New Yorker (Sep. 7, 2009), http://www.newyorker.com/magazine /2009/09/07/trial-by-fire [https:// perma.cc/S2EB-4E64].

18. Id.

19. Id.

20. Id.

21. Id. 
article, have played a large role in shaking public confidence in the system.

In Herrera $v$. Collins, ${ }^{22}$ a majority of the justices of the Unites States Supreme Court agreed that "the execution of a legally and factually innocent person would be a constitutionally intolerable event." "23 The Court, however, has done little to ensure that this is prevented. It has failed to recognize the right of death row inmates to make a stand-alone, actual innocence claim. ${ }^{24}$ The Court has also held that inmates have no constitutional right to post-conviction DNA testing. ${ }^{25}$ The Court has also refused to police the states' clemency process. ${ }^{26}$

\section{B. Race}

Another reason for the declining support is the concern over the continued racial disparities in the administration of the death penalty. Racism in the implementation of the death penalty does not appear to be a relic of the past. ${ }^{27}$ African-Americans continue to be sentenced to death and executed disproportionately. African-Americans constitute roughly $13 \%$ of the U.S. population, ${ }^{28}$ yet they account for about $42 \%$ of the death row population ${ }^{29}$ and approximately $35 \%$ of all executions in the U.S. since $1976 .{ }^{30}$ It is also troubling that the vast majority

22. Herrera v. Collins, 506 U.S. 390 (1993).

23. Id. at 419 (O'Connor, J., concurring).

24. See id. at 416 (justifying the refusal to recognize an actual innocence claim because "the trial is the paramount event for determining the guilt or innocence of the defendant."); see also In re Davis, 557 U.S. 952, 955 (2009) (Scalia, J., dissenting) ("This court has never held that the Constitution forbids the execution of a convicted defendant who has had a full and fair trial but is later able to convince a habeas court that he is 'actually' innocent." (emphasis in original)).

25. See District Attorney's Office for the Third Jud. Dist. v. Osborne, 557 U.S. 52 (2009) (holding that state inmate had no right under the due process clause to postconviction access to DNA evidence).

26. See Ohio Adult Parole Auth. v. Woodard, 523 U.S. 272 (1997).

27. See generally Carol S. Steiker \& Jordan M. Steiker, The American Death Penalty and the (In)visibility of Race, 82 U. CHI. L. Rev. 243, 245-253 (2015) (reviewing the history of the racially disproportionate use of the death penalty in the United States).

28. QuickFacts, U.S. Census BurEAU, https://www.census.gov/quickfacts/table/PST04 5215/00 (last visited Nov. 10, 2016) (go to "TABLE," "PEOPLE," and "Race and Hispanic Origin" subheading) [https://perma.cc/B7SB-8CNM].

29. Facts, Death Penalty Info. Ctr., supra note 9 (table labeled "Death Row Inmates by Race").

30. Race of Death Row Inmates Executed Since 1976, Death Penalty Info. Ctr., (Dec. 9, 2016), http://www.deathpenaltyinfo.org/race-death-row-inmates-executed-1976 [https:// perma.cc/VB2Y-S3ML] [hereinafter Race, Death Penalty Info. CTr.]. 
of those who have been executed killed white victims, ${ }^{31}$ despite the fact that approximately $44 \%$ of murder victims in the United States are African-American. ${ }^{32}$ Since $1976,76 \%$ of people who have been executed killed white victims. ${ }^{33}$ Thus, because African-Americans are almost one half of all homicide victims, this means that their killers are, for the most part, not being sentenced to death and executed. Numerous studies have concluded that these disparities are the result of racial discrimination in the administration of the death penalty. ${ }^{34}$ The most prominent study to reach such a conclusion was the Baldus study, which purports to show a disparity in the imposition of the death penalty in Georgia based on the race of the murder victim and, to a lesser extent, the race of the defendant. ${ }^{35}$ The Baldus study took into account 230 variables "that could have explained the [racial] disparities" in capital sentencing "on non-racial grounds." 36 Even after taking account of these variables, the Baldus study found that defendants charged with killing white victims were 4.3 times more likely to receive a death sentence than defendants charged with killing blacks and others. ${ }^{37}$ The study also found that black defendants were 1.1 times as likely to receive a death sentence as other defendants. ${ }^{38}$ The study concluded that black defendants who kill white victims have a greater likelihood of receiving the death penalty than any other defendant-victim combination. ${ }^{39}$

31. See id.

32. See Uniform Crime Report; Expanded Homicide Data Table 6: Murder Race, Ethnicity, and Sex of Victim by Race, Ethnicity, and Sex of Offender, Fed. Bureau of Investigation, (2013), https://ucr.fbi.gov/crime-in-the-u.s/2013/crime-in-the-u.s.-2013/offenses-known-to-lawenforcement/expanded-homicide/expanded_homicide_data_table_6_murder_race_and_ sex _of_vicitm_by_race_and_sex_of_offender_2013.xls [https://perma.cc/323C-8EZ9] (in 2013 there were a total of 5,723 murder victims and 2,491, or approximately $44 \%$ were African-American).

33. Race, Death Penalty Info. Ctr., supra note 30.

34. See, e.g., D. Baldus et al., Racial Discrimination and the Death Penalty in the PostFurman Era: An Empirical and Legal Overview, With Recent Findings From Philadelphia, 83 CorNELl L. Rev. 1638, 1738 (1998) (based on its study of Philadelphia's administration of its death penalty, finding "that the problem of arbitrariness and discrimination in the administration of the death penalty is a matter of continuing concern and is not confined to southern jurisdictions."); S. Phillips, Racial Disparities in the Capital of Capital Punishment, 45 Hous. L. Rev. 807, 833-834 (2008) (finding that the Harris County District Attorney was considerably more likely to pursue death against black defendants even when their crimes are less serious).

35. McCleskey v. Kemp, 481 U.S. 279, 287 (1987).

36. Id.

37. Id.

38. Id.

39. Id. 
The Supreme Court had largely ignored the issue of racial disparities in capital sentencing, but the strength of the Baldus findings forced it to finally confront the issue in 1987. In McCleskey v. Kemp, although the Court accepted the legitimacy of the Baldus study, ${ }^{40}$ it did not allow the inmate to use the statistics as proof of racial discrimination. ${ }^{41}$ Rather, the Court held that in order to prevail on a claim of racial discrimination in capital sentencing, a death row inmate would have to prove that the decisionmakers in his specific case acted with discriminatory purpose or that a capital sentencing statute was enacted by the legislature with a discriminatory purpose. ${ }^{42}$ Not surprisingly, given this onerous standard, no death row inmate has been able to prove racial discrimination in capital sentencing. ${ }^{43}$

A major reason racial disparities in capital sentencing persist is because those who decide whether the defendant lives or dies are overwhelmingly white:

[T] he criminal justice system is the part of American society that has been least affected by the Civil Rights Movement. Many courthouses throughout the country look about the same today as they did in the 1940s and 1950s. The judges are white, the prosecutors are white, and the court-appointed lawyers are white. Even in communities with fairly substantial African American populations, all of the jurors at a trial may be white. ${ }^{44}$

According to a recent study, $95 \%$ of elected state and local prosecutors are white. ${ }^{45}$ These overwhelmingly white prosecutors make the decision whether to seek death in a particular case. They also have a big influence over who sits on the jury in a capital case. Prosecutors are obviously aware of the fact that many African-Americans perceive the criminal justice system to be biased. As a result, a jury composed of African-Americans is significantly less likely to return a death verdict. ${ }^{46}$ Therefore, prosecutors have an incentive to remove as many African-

40. Id. at $291 \mathrm{n} .7$.

41. McCleskey, 481 U.S. at 291-92.

42. Id. at 297-98.

43. Kenneth Williams, Most Deserving of Death? An Analysis of the Supreme Court's Death Penalty Jurisprudence 45 (2012) (finding that no death row inmate alleging racial discrimination has prevailed on a McCleskey claim).

44. Stephen B. Bright, The Failure to Achieve Fairness: Race and Poverty Continue to Influence Who Dies, 11 U. P. J. Const L. 23, 27 (2008).

45. See Nicholas Fandos, A Study Documents the Paucity of Black Elected Prosecutors: Zero in Most States, N.Y. Times (July 7, 2015), http://www.nytimes.com/2015/07/07/us/ a-study-documents-the-paucity-of-black-elected-prosecutors-zero-in-most-states.html?_r=0 [https://perma.cc/L9GD-3FUA].

46. See William J. Bowers, Benjamin D. Steiner \& Marla Sandys, Death Sentencing in Black and White: An Empirical Analysis of the Role of Juror's Race and Jury Racial Composition, 3 U. PA. J. Const. L. 171, 195 (2001). 
Americans from a capital jury as they possibly can, and they often do so through the use of peremptory challenges. ${ }^{47}$ Several studies have documented the continuing use of peremptory challenges to strike African-Americans from the jury in capital cases. ${ }^{48}$

In Batson v. Kentucky, ${ }^{49}$ the Supreme Court outlawed the use of race in the exercise of peremptory challenges. Despite Batson, courts have tended to uphold the prosecutors' use of peremptory challenges against African-American members of the jury pool because "[r]acebased peremptory strikes are almost always invisible, or at least, as Batson has shown, hard to prove." ${ }^{50}$ As long as the prosecutor can articulate a race neutral reason for the strike, the courts will usually reject the defense's Batson challenge. ${ }^{51}$ This is so even when the prosecutor offers an absurd reason for striking black jurors, such as the fact that a juror agrees with the verdict in the O.J. Simpson case, ${ }^{52}$ or that the potential juror has facial hair. ${ }^{53}$ Despite the continued use of peremptory challenges to remove black jurors from capital cases, the Supreme Court has refused to strengthen Batson.

\section{Arbitrariness}

In 1972, the Court struck down the death penalty-despite no prior attempts to regulate it ${ }^{54}$-primarily because of the arbitrary manner in which the death penalty was imposed at the time. ${ }^{55}$ The Court began to regulate the death penalty in 1976 with its decision in Gregg v. Georgia. ${ }^{56}$ Its foremost goal in doing so was to minimize the arbitrary application of the death penalty. The Justices were troubled by the fact that, in their view, the death penalty "smacks of little more than a lottery system." ${ }^{57}$ However, in Gregg, a substantial majority of

47. See Miller-El v. Dretke, 545 U.S. 231, 268-271 (2005) (Breyer, J., concurring) (citing evidence and studies that despite Batson, the use of peremptory challenges based on race remains a problem).

48. See Bright supra note 44 at $27 \mathrm{n} .15$ (discussing the racially-motivated practices of the Philadelphia and Houston District Attorneys).

49. Batson v. Kentucky, 476 U.S. 79 (1986).

50. See Gilad Edelman, Why Is It So Easy For Prosecutors To Strike Black Jurors?, ThE New Yorker (June 5, 2015), http://www.newyorker.com/news/news-desk/why-is-it-so-easyfor-prosecutors-to-strike-black-jurors (italics added) [https://perma.cc/5LBT-PBUK].

51. Id.

52. See Shelling v. State, 52 S.W.3d 213 (Tex. App. 2001).

53. See Purkett v. Elem, 514 U.S. 765, 768 (1995).

54. See Williams, supra note 43, at 7-10 (2012).

55. See Furman v. Georgia, 408 U.S. 238 (1972).

56. Gregg v. Georgia, 428 U.S. 153 (1976); see Callins v. Collins, 510 U.S. 1141, 1145-47 (1994) (Blackmun, J., dissenting).

57. Id. at 293 . 
the Court believed that the death penalty could be imposed less arbitrarily. ${ }^{58}$ In particular, the Court approved of three safeguards that it believed would minimize arbitrariness: (1) require the jury to consider the circumstances of the crime and the defendant's background at a separate sentencing hearing; ${ }^{59}$ (2) limit the sentencer's discretion by providing guidance as to which aggravating circumstances could warrant the death penalty; ${ }^{60}$ and (3) an automatic appeals process as a check on arbitrary decision making. ${ }^{61}$ The decision in Gregg began the modern era of capital punishment in the United States. During this modern era, the Court would closely regulate the death penalty by restricting its use to certain categories of defendants ${ }^{62}$ and certain crimes and by mandating that the defendant be allowed to present mitigating evidence. ${ }^{63}$

Despite this effort, the Court's attempt to restrict the death penalty to those most deserving of death has failed. The death penalty today is as arbitrary as it was when the Court decided Furman. Several Justices who have had to administer the death penalty over the years have acknowledged that the Court's attempt to regulate the death penalty has been a failure. ${ }^{64}$

58. Id. at $188-89$.

59. Id. at 191-92.

60. Id. at 192-94.

61. Id. at 195 .

62. See Roper v. Simmons, 543 U.S. 551, 571-75 (2005) (holding that the death penalty could not be imposed on juvenile offenders); Atkins v. Virginia, 536 U.S. 304, 319 (2002) (holding that the death penalty could not be imposed on those defendants who are intellectually disabled); Ford v. Wainwright, 477 U.S. 399, 410 (1986) (holding that the death penalty could not be imposed on those inmates who became insane while incarcerated); Coker v. Georgia, 433 U.S. 584, 598 (1977) (holding that death could not be the punishment for the crime of rape); Kennedy v. Louisiana, 554 U.S. 407, 413 (2008) (prohibiting the death penalty for child rapists who do not kill).

63. See Lockett v. Ohio, 438 U.S. 586, 608 (1978).

64. In Callins v. Collins, Justice Blackmun announced:

From this day forward, I no longer shall tinker with the machinery of death . . . I feel morally and intellectually obligated simply to concede that the death penalty experiment has failed... The basic question-does the system accurately and consistently determine which defendants 'deserve' to die?-cannot be answered in the affirmative.

510 U.S. 1141, 1145 (1994) (Blackmun, J., dissenting). In Baze v. Rees, Justice Stevens wrote that "[f]ull recognition of the diminishing force of the principal rationales for retaining the death penalty should lead this Court and legislatures to reexamine the question recently posed by Professor Salinas, a former Texas prosecutor and judge: 'Is it time to Kill the Death Penalty?'” 553 U.S. 35, 81 (2008) (Stevens, J., concurring). Justice Lewis Powell told his biographer that "I have come to think that capital punishment should be abolished.” John C. Jeffries JR., Justice Lewis F. Powell, Jr. 451-52 (1994). 
Why does the death penalty continue to be imposed arbitrarily despite almost forty years of regulation by the Supreme Court? There are several reasons. First, as pointed out earlier, ${ }^{65}$ the racial disparities in every jurisdiction that administers the death penalty ${ }^{66}$ strongly suggest that it is being imposed in a racially discriminatory manner. Second, only a small fraction of murderers are actually sentenced to death. ${ }^{67}$ The murders they commit are often less egregious than many defendants who did not receive death sentences. ${ }^{68}$ Third, gender plays a role in that women are rarely sentenced to death. ${ }^{69}$ Fourth, geography plays a huge role: Where a defendant killed his victim is extremely important. ${ }^{70}$ A killer in Indiana is much less likely to be sentenced to death than a similar killer in Texas. ${ }^{71}$ Even within an active death penalty state, the imposition of the death penalty is heavily dependent on where the killing occurred within a state. ${ }^{72}$ For instance, a killer in Houston is much more likely to be sentenced to

65. Supra Part I.B.

66. See Steiker \& Steiker, supra note 27.

67. According to the FBI, in 2013 there were 5,723 murder victims. See Uniform Crime Report, supra note 32. Yet in 2013 only 83 individuals were sentenced to death. See By Year, Death Penalty Info. Ctr., supra note 4.

68. See Glossip v. Gross, 135 S. Ct. 2726, 2760 (2015) (Breyer, J., dissenting) (discussing a study conducted in Connecticut that found only one of every nine defendants sentenced to death were the "worst of the worst").

69. Women constitute less than $2 \%$ of the death row population. Facts, Death PeNALtY INFo. CTR., supra note 9. In light of this reality, defendants in this article are often referred to in the abstract as male.

70. See Glossip, 135 S. Ct. at 2761 (Breyer, J., dissenting).

71. See Number of Executions by State and Region, Death Penalty Info. Ctr. (Dec. 9, 2016), http://www.deathpenaltyinfo.org/number-executions-state-and-region-1976 [https://perma.cc/UJ9R-98FV] [hereinafter Number, Death Penalty Info. CTR.] (Texas has executed a total of 538 defendants, whereas Indiana has executed 20); Stephen B. Bright, The Role of Race, Poverty, Intellectual Disability, and Mental Illness in the Decline of the Death Penalty, 49 U. Rich. L. Rev. 671, 673 (2015) (pointing out that $20 \%$ of U.S. counties are responsible for the entire death row population).

72. See Robert J. Smith, The Geography of the Death Penalty and its Ramifications, 92 B.U. L. REv. 227, 231-32 (2012); John J. Donohue III, An Empirical Evaluation of the Connecticut Death Penalty System Since 1973: Are there Unlawful Racial, Gender, and Geographic Disparities?, 11 J. Empirical Legal Studies 637, 673 (2014) (“[T] he single most important influence from 1973-2007 explaining whether a death-eligible defendant [in Connecticut] would be sentenced to death was whether the crime occurred in Waterbury [County]."); Campbell Robertson, The Prosecutor Who Says Louisiana Should 'Kill More People', N.Y. Times (July 7, 2015), http://www.nytimes.com/2015/07/08/us/louisiana-prosecutor-becomes-bluntspokesman-for-death-penalty.html [https://perma.cc/9K7N-R775] ("Within Louisiana, where capital punishment has declined steeply, Caddo [Parish county] has become an outlier, accounting for fewer than $5 \%$ of the state's death sentences in the early 1980 s but nearly half over the past five years."). 
death than a similar killer in Austin. ${ }^{73}$ Finally, the availability of resources are a crucial factor in whether the death penalty is imposed, ${ }^{74}$ as some jurisdictions provide more resources for indigent defense than others. ${ }^{75}$ This is important because defendants who are represented by competent trial counsel are significantly less likely to receive a death sentence. ${ }^{76}$

In determining who is sentenced to death, the egregiousness of the crime is a much less important factor than the race of the victim and defendant, the gender of the defendant, where the crime occurred, and the quality of defense counsel.

\section{Incompetent Lawyers}

The public has learned that it is usually not the heinousness of the crime that causes a defendant to end up on death row. Rather, it is often the quality of the legal representation received that is dispositive. ${ }^{77}$ Defendants have ended up on death row because their lawyers slept during the trial, ${ }^{78}$ were drunk and disoriented at trial, ${ }^{79}$ failed to present important evidence, ${ }^{80}$ failed to understand the law, ${ }^{81}$ and because their lawyers simply failed to vigorously defend their clients. ${ }^{82} \mathrm{It}$ is difficult for the public to have any confidence in a system that determines who should live or die when one of the key players in that system, the defense counsel, is incompetent.

There are several terrible consequences for capital defendants who receive substandard legal representation. The most serious conse-

73. See Donohue, supra note 72 at 680-81 (pointing out that Harris County [Houston] is responsible for more executions than all states other than Texas itself).

74. See Glossip, 135 S. Ct. at 2761 (Breyer, J., dissenting) (pointing to scholars that suggest that such disparities in resources could also account for the aforementioned geographical discrepancies).

75. See Gideon's Broken Promise: America's Quest for Equal Justice, Am. Bar Assn. Standing Committee on Legal Aid and Indigent Defendants 7-9 (Dec. 2004), http://www.ameri canbar.org/content/dam/aba/administrative/legal_aid_indigent_defendants/ls_sclaid_ def_bp_right_to_counsel_in_criminal_proceedings.authcheckdam.pdf [https://perma .cc/CX62-J2VR].

76. See Stephen B. Bright, Counsel for the Poor: The Death Sentence Not for the Worst Crime but for the Worst Lawyer, 103 YALE L. J. 1835, 1837-41 (1994).

77. Id. at 1836 ("Poor people accused of capital crimes are often defended by lawyers who lack the skills, resources, and commitment to handle such serious matters.").

78. See, e.g., Burdine, v. Johnson, 262 F.3d 336, 338 (5th Cir. 2001).

79. See Bright, supra note 76 , at 1835 .

80. Id. at 1837 .

81. See Hinton v. Alabama, 134 S. Ct. 1081, 1085 (2014) (trial attorney failed to seek funding for expert because he was not aware that the law authorized such funding).

82. See Bright, supra note 76 , at 1835-36. 
quence is that they may be wrongly convicted. Another consequence of bad lawyering in capital cases is the possibility that the defendant will be sentenced to death even though he should not be. There have been numerous defendants who have been sentenced to death because their lawyers failed to present important mitigating evidence to the jury. ${ }^{83}$ Incompetent trial lawyers also make it difficult for defendants to receive appellate relief because they may fail to make timely objections at trial, thereby relinquishing the ability to preserve error for appeal. ${ }^{84}$

The Supreme Court attempted to address the problem of incompetent counsel in its decision in Strickland v. Washington. ${ }^{85}$ In Strickland, the Court held that in order to prevail on a claim that counsel provided ineffective representation, the defendant must prove (1) the counsel's performance was deficient, and (2) that the defendant was prejudiced as a result of counsel's deficient performance. ${ }^{86}$ It is very difficult for a defendant to prevail on a claim of ineffective assistance of counsel. Even if the defendant can prove that counsel's performance was deficient-which is no easy task-courts often reject claims of ineffective assistance of counsel on grounds that the defendant did not suffer prejudice. ${ }^{87}$

\section{E. Other Factors}

Several other factors have contributed to the loss of public confidence in the administration of the death penalty.

\section{i. Delay in Implementation}

The few who are sentenced to death are not likely to be executed. They are more likely to have their sentences overturned or die from

83. See e.g., Neal v. Puckett, 286 F.3d 230, 233 (5th Cir. 2002) (trial counsel failed to present evidence during punishment phase of petitioner's background-including his horrid childhood of rejection, abandonment, and mental institutions, plus his tortuous prison experience).

84. See e.g., Henson v. State, 407 S.W.3d 764, 767 (Tex. Crim. App. 2013) ("In order to preserve error for appellate review a defendant must make a timely request, objection or motion in the trial court (regardless of whether or not the error complained of is constitutional).").

85. Strickland v. Washington, 466 U.S. 668 (1984).

86. Id. at 687 .

87. See e.g., Kenneth Williams, Does Strickland Prejudice Defendants on Death Row?, 43 U. Rich. L. Rev. 1459, 1481-1485 (2009) (discussing the case of Johnny Ray Conner); Wesley v. Johnson, 83 F.3d 714, 721 (5th Cir. 1996) (holding that although trial counsel was deficient for failing to review transcript of co-defendant's trial, this failure did not prejudice petitioner). 
natural causes than to be executed. ${ }^{88}$ "In a word, executions are rare." ${ }^{89}$ For the unlucky few who are executed, it takes on average of approximately eighteen years to carry out. ${ }^{90}$ This delay is attributable to a lengthy appellate process, ${ }^{91}$ which seeks to ensure reliability and fairness before the ultimate punishment is meted out. ${ }^{92}$ However, the lengthy delay in carrying out the death penalty undermines the penological justifications for the death penalty, specifically the deterrence rationale. ${ }^{93}$ The question whether the death penalty actually deters is uncertain. ${ }^{94}$ There are studies that both support and undermine the deterrence rationale of the death penalty. ${ }^{95}$ Most would agree that, to be an effective deterrent, executions have to be carried out swiftly. ${ }^{96}$ Public support has diminished as a result of the lengthy delays. There is also no solution to the problem of lengthy delays as long as we are committed to reliability and fairness. As Justice Breyer explained, "[i]n this world, or at least in this Nation, we can have a death penalty that at least arguably serves legitimate penological purposes or we can have a procedural system that at least arguably seeks reliability and fairness in the death penalty's application. We cannot have both."97

\section{ii. Life Without Parole}

In the past, jurors often voted for death in order to ensure that dangerous defendants remained in jail and were never released on

88. Glossip v. Gross, 135 S. Ct. 2726, 2768 (2015) (Breyer, J., dissenting).

89. Id. (emphasis in original).

90. Id. at 2770 .

91. An inmate sentenced to death has a right to have his conviction and sentence reviewed on direct appeal. Once his direct appeal has been concluded, he or she can file a writ of habeas corpus in state court. If the state courts deny relief, the inmate can file a writ of habeas corpus in federal court. See Kenneth Williams, Most Deserving of Death? An Analysis of the Supreme Court's Death Penalty Jurisprudence 111 (2012).

92. See generally Kenneth Williams, The Antiterrorism and Effective Death Penalty Act: What's Wrong With It and How to Fix It, 33 ConN. L. Rev. 919, 921 (2001) (discussing the basics of the writ of habeas corpus and direct review). Whether the appellate process actually accomplishes these objectives is certainly subject to debate because appellate courts are often constrained in their ability to review the merits of an inmate's appeals by doctrines such as procedural default, harmless error, exhaustion, and-most importantly in the federal courts-by the Anti-Terrorism and Effective Death Penalty Act of 1996, 110 Stat. 1214. Id. at $924-927$.

93. The Supreme Court has identified two penological justifications for the death penalty: deterrence of capital crimes by prospective offenders and retribution. Gregg v. Georgia, 428 U.S. 153, 183 (1976).

94. Glossip, 135 S. Ct. at 2767-69 (2015) (Breyer, J., dissenting).

95. Id.

96. See e.g., Furman v. Georgia, 408 U.S. 238, 302 (1972) (Brennan, J., concurring).

97. Glossip, 135 S. Ct. at 2772 (Breyer, J., dissenting) (emphasis in original). 
parole. ${ }^{98}$ Now that most states provide jurors with the option of sentencing the defendant to life without parole ("LWOP"), this concern is eliminated. As a result, jurors are meting out fewer death sentences $^{99}$ and the public seems to agree with those decisions. In a recent poll, $52 \%$ of the public preferred LWOP, whereas $42 \%$ preferred the death penalty. ${ }^{100}$ Even among those who support the death penalty, 29\% preferred LWOP. The public is increasingly unwilling to accept the risk of executing an innocent person now that they are assured that the perpetrator will never be released from prison.

\section{iii. Religion}

There was a time when practically every organized religious denomination supported capital punishment. ${ }^{101}$ That is no longer the case. In fact, most major Christian denominations have announced their opposition to capital punishment. ${ }^{102}$ Many non-Christian denominations, such as reform Jews and Unitarian Universalists, have also announced their opposition to capital punishment. ${ }^{103}$ The religious denomination that opposes the death penalty most aggressively has been the Catholic Church. The Catholic Church's opposition is based on its belief in the sanctity of human life. ${ }^{104}$ Pope John Paul II has stated that all human life deserves respect, "even [the lives] of

98. See Amanda Dowlen, An Analysis of Texas Capital Sentencing Procedure: Is Texas Denying Its Capital Defendants Due Process By Keeping Judges Uninformed of Parole Eligibility?, 29 TEx. Tech L. Rev. 1111, 1134-1138 (1998).

99. By Year, Death Penalty Info. Ctr., supra note 4.

100. Damla Ergun, New Low in Preference for the Death Penalty, ABC News (June 5, 2014), http:/ /abcnews.go.com/blogs/politics/2014/06/new-low-in-preference-for-the-death-penalty/ [https://perma.cc/5CAQ-8BHD].

101. See generally Davison M. Douglas, God and the Executioner: The Influence of Western Religion on the Death Penalty, 9 WM. \& Mary Bill RTs. J. 137, 142-61 (2000) (providing a history of organized religious denominations and their attitudes toward capital punishment).

102. For information on religious denominations and their position on the death penalty, see Religion and the Death Penalty, Death Penalty Info. Ctr. http://www.deathpenaltyinfo.org/article.php\%3Fdid\%3D2249 (last visited Nov. 20, 2016) [https://perma.cc/ NG3A-JCEC]. Notable exceptions to the majority include the Church of Jesus Christ of Latter Day Saints, which leaves the question up to "civil law;" The National Association of Evangelicals, which supports both proponents and opponents of the death penalty; and The Southern Baptist Association, which supports "fair and equitable use of" the death penalty. Id.

103. Id. See also, Religious Groups Official Positions on Capital Punishment, Pew RESEARCH CTR. (Nov. 4, 2009), http://www.pewforum.org/2009/11/04/religious-groups-offi cial-positions-on-capital-punishment/ [https://perma.cc/B4S3-65KK].

104. Thomas C. Berg, Religious Conservatives and the Death Penalty, 9 WM. \& MAry BILL RTs. J. 31, 42 (2000). 
criminals and unjust aggressors." 105 According to the Pope, since human life "from the beginning . . . involved the "creative action of God' and remains forever in a special relationship with the Creator, only God is the master of life."106 Therefore, the government

ought not go to the extreme of executing the offender except in cases of absolute necessity; in other words, when it would not be possible otherwise to defend society. Today, however, as a result of steady improvements in the organization of the penal system, such cases are very rare, if not practically non-existent. ${ }^{107}$

These religious objections, especially the Catholic Church's work against the death penalty, have likely had an impact on the declining support for the death penalty in the United States. ${ }^{108}$

\section{Reform or Abolition?}

A longtime federal judge, Alex Kozinski, recently wrote that there are "reasons to doubt that our criminal justice system is fundamentally just." 109 As some of the problems discussed in the previous section illustrate, nowhere is his conclusion more evident than in the administration of the death penalty. There is a consensus emerging across ideological and political lines that the death penalty is seriously flawed. ${ }^{110}$ This section discusses the option of continued reform and why that option is likely to fail.

\section{A. Reform}

There have been numerous proposals to "fix" the death penalty. Reform proposals have been made by academics, ${ }^{111}$ state commison-the-death-penalty/ [https://perma.cc/4ZHW-3FE9] ("I think the religious community has played an enormous role in having people question their consciences' about where they stand on the death penalty. . . The pope's visit to the United States had a powerful influence on the Catholic community . . . in reconsidering their view.").

109. Hon. Alex Kozinski, Criminal Law 2.0, 44 Geo. L.J. Ann. Rev. Crim. Proc. iii, xiii (2015).

110. See, e.g., Conservatives Concerned About the Death Penalty, http://conserva tivesconcerned.org (last visited Nov. 20, 2016) [https://perma.cc/YXT6-QBK4].

111. See, e.g., Kenneth Williams, The Death Penalty: Can It be Fixed?, 51 Cath. U.L. Rev. $1177,1180-1203$ (2002) (discussing various potential reforms to the death penalty, but subsequently critiquing them).
} 
sions, ${ }^{112}$ and others to address many of the areas of concern outlined in the previous section. Below is a review and assessment of some of these proposals.

\section{i. Race}

An attempt to eliminate racial disparity in capital sentencing failed at the Supreme Court in McCleskey v. Kemp. ${ }^{113}$ Since then, two major legislative proposals have been advanced in the attempt to eliminate racial disparities in capital sentencing.

First, in federal cases, a federal statute was enacted in 2013 that attempts to eliminate racism in the jury deliberation process. ${ }^{114}$ This statute requires that the judge instruct the jury at the end of the sentencing phase of a capital case that they may not in any way consider race, national origin, sex, or the religious beliefs of the defendant or the victim in reaching its verdict. ${ }^{115}$ The same statute also requires that after a verdict has been rendered, all jurors must certify that they did not, in fact, consider the race, national origin, sex, or religious beliefs of the defendant or the victim in reaching their determinations and that their determinations would have been the same regardless of these factors. ${ }^{116}$ Despite this statute, there continue to be racial disparities in the administration of the federal death penalty. ${ }^{117}$

112. See, e.g., Report of the Governor's Commission on Capital Punishment (April 15, 2002), http://illinoismurderindictments.law.northwestern.edu/docs/Illinois_Moratorium _Commission_complete-report.pdf [https://perma.cc/6KY8-KXDJ] (presenting various recommendations to reform the death penalty to Governor George Ryan of Illinois after a moratorium on executions was declared).

113. McCleskey v. Kemp, 481 U.S. 279 (1987).

114. See 18 U.S.C. $\$ 3593(f)$ (2013).

115. Id.

116. Id.

117. About $44 \%$ of federal death row inmates are black, $39 \%$ are white and $13 \%$ are Latino. See Federal Death Row Inmates, Death Penalty Info. Ctr. (Mar. 24, 2016), http:/ / www.deathpenaltyinfo.org/federal-death-row-prisoners [https://perma.cc/DW4S-VTGL]. In addition, the U.S. Department of Justice studied the federal death penalty system and found that, from 1988 to 2000 , approximately $80 \%$ of the cases submitted by federal prosecutors for death penalty review involved racial minorities as defendants. See Report on the Federal Death Penalty System: A Statistical Survey 1988-2000, Office of the Deputy AtтorNEY GEN. http://www.justice.gov/dag/survey-federal-death-penalty-system [https://perma .cc/L9FS-D26C] (go to link titled "Table Set I: Statistical Overview"). About 73\% of cases approved for death penalty prosecution involved minority defendants. Id. The study also found that U.S. Attorneys were almost twice as likely to recommend the death penalty for a black defendant when the victim was non-black as when the victim was black. Id. (go to link titled "Victims: Explanatory Notes For Table Set III.C"). The study further found that white defendants were almost twice as likely as black, Hispanic, or other defendants to be offered a plea agreement reducing the penalty from death to life imprisonment or less. See Statement of David C. Baldus to Hon. Russell D. Feingold, Comm. on the Judiciary, U.S. Senate 
The second legislative proposal to eliminate racial disparities in the administration of the death penalty was the Racial Justice Act. ${ }^{118}$ Had the Racial Justice Act passed, it would have allowed defendants who had been sentenced to death to use statistical evidence to demonstrate a prima facie case of racial bias, ${ }^{119}$ something that the Supreme Court did not permit in McCleskey. ${ }^{120}$ The burden then would have shifted to the prosecution to explain the reason for the statistical disparity. ${ }^{121}$ The reviewing court would then decide whether race was a factor, and if it found that it was, the defendant's death sentence would be overturned. ${ }^{122}$ The Racial Justice Act would have required an explanation from prosecutors when racial disparities existed.

Requiring an explanation from prosecutors is important:

It is not unreasonable to require publicly elected prosecutors to justify racial disparities in capital prosecutions. If there is an underrepresentation of black citizens in a jury pool, jury commissioners are required to explain the disparity. A prosecutor who strikes a disproportionate number of black citizens in selecting a jury is required to rebut the inference of discrimination by showing race neutral reasons for his or her strikes. If there are valid, race neutral explanations for the disparities in capital prosecutions, they should be presented to the courts and public. Prosecutors, like other public officials, should be held accountable for their actions. The bases for critical decisions about whether to seek the death penalty and whether to agree to a sentence less than death in exchange for a guilty plea should not be shrouded in secrecy, but should be openly set out, defended, and evaluated. ${ }^{123}$

Ultimately, the Racial Justice Act passed the U.S. House of Representatives but failed to be acted upon by the U.S. Senate. ${ }^{124}$ Two states, North Carolina and Kentucky, enacted versions of the Act. ${ }^{125}$ However, after a state judge overturned an inmate's death sentence based

(June 11, 2001), http://www.deathpenaltyinfo.org/node/86 [https://perma.cc/TW24ZAGG] (" $48 \%$ of white defendants avoid the risk of a death penalty by entering a plea agreement to a non-capital charge, while the rates that blacks and Hispanics enter such agreements are $25 \%$ and $28 \%$ respectively.").

118. Racial Justice Act, H.R. 4017, 103d Cong. § 2921 (2d Sess. 1994).

119. Williams, supra note 111 , at 1182-83.

120. See McCleskey v. Kemp, 481 U.S. 279, 297 (1987).

121. Williams, supra note 111 , at 1183.

122. Id.

123. Stephen B. Bright, Discrimination, Death and Denial: The Tolerance of Racial Discrimination in Infliction of the Death Penalty, 35 Santa Clara L. Rev. 433, 465-66 (1995).

124. See Erwin Chemerinsky, Eliminating Discrimination in Administering the Death Penalty: The Need for the Racial Justice Act, 35 Santa Clara L. Rev. 519, 530 (1995).

125. Williams, supra note 43 , at 49 . 
on the statute, the North Carolina legislature repealed its Racial Justice Act. ${ }^{126}$

Given these practical and political difficulties faced by Congress, the prospects for any legislative reforms designed to address the problem of racial disparities in capital sentencing are bleak. Furthermore, the Supreme Court has always been unwilling to address the issue of race and capital punishment. ${ }^{127}$ Even in the unlikely event that either the Supreme Court or the legislature addressed the issue, it is questionable how much can be achieved in ending these disparities. The United States has been grappling with the issue of race since its inception. Racism, however, is not a relic of the past. A federal appellate court recently acknowledged "the sad truth that racism continues to exist in our modern American society despite years of laws designed to eradicate it." 128 As long as there continues to be significant racial prejudice in society, it is difficult to imagine any reform capable of eliminating the racial disparities that have always infected the highlycharged decision whether to sentence an individual to death. Even the Racial Justice Act, although well intended, would not have done so. The Act was modeled after Batson and as discussed earlier, judges have largely ignored obvious racism in jury selection. ${ }^{129}$ Therefore, there is no reason to believe that the courts would do a better job enforcing the Racial Justice Act, even if it were to be enacted.

\section{ii. Innocence}

There are several causes of wrongful convictions. Wrongful convictions often occur because of erroneous eyewitness testimony, which has been described as "the single greatest cause of wrongful convic-

126. See Lane Florsheim, Four Inmates Might Return to Death Row Because North Carolina Republicans Repealed a Racial Justice Law, New Republic (May 9, 2014), http://www.newre public.com/article/117699/repeal-racial-justice-act-north-carolina-gop-takeover [https:// perma.cc/WK5C-8HBY]; North Carolina Racial Justice Act Repealed Shortly After First Use, AMERican Bar Ass'n: Death Penalty Representation Project, http://www.americanbar.org/ publications/project_press/2012/year-end/RJA_update_2012.html [https://perma.cc/ KH9F-34VL].

127. See Steiker \& Steiker, supra note 27.

128. Veasey v. Abbott, 796 F.3d 487, 499 (5th Cir. 2015); The recent questionable shootings of numerous unarmed African-American men by police officers is another example of the continued racism in American society despite the enactment of laws such as 18 U.S.C § 242 (1996) to prevent such shootings. For a discussion of police shootings of unarmed African-American men, see Manny Fernandez, North Charleston Police Shooting Not Justified, Experts Say, N.Y. Times (Apr. 9, 2015), http://www.nytimes.com/2015/04/ 10/us/north-charleston-police-shooting-not-justified-experts-say.html?_r=0 [https://perma .cc/9AAA-FRXT].

129. See Edelman, supra note 50. 
tions in the U.S. criminal justice system." 130 Several factors cause witnesses to misidentify suspects. First, the stress of witnessing a traumatic event like murder may affect a witness' perception. ${ }^{131}$ Second, witnesses often make misidentifications when identifying persons of a different race. ${ }^{132}$ Third, the procedure used by law enforcement officers may cause a witness to identify the wrong person. ${ }^{133}$ For instance, a suggestive lineup could cause a misidentification. ${ }^{134}$ A lineup administered by a police officer who is familiar with the suspect can also cause misidentifications. ${ }^{135}$

Several proposals have been made to minimize the possibility of a misidentification. One such proposal is that lineups be administered by officers who are not involved in the investigation and who are not familiar with the suspect. ${ }^{136}$ To address the problem of suggestive lineups, some have proposed that individuals in a lineup be presented sequentially so that witnesses would not be able to compare and contrast the individuals in the lineup and pick the individual who most resembles the suspect. ${ }^{137}$ Another potential source of misidentification comes from the fact that witnesses often believe that the suspect is part of the lineup and therefore feel pressure to pick someone in the lineup as the perpetrator. ${ }^{138}$ Some have proposed informing witnesses that the suspect may not be in the lineup to reduce this pressure. ${ }^{139}$

Another cause of wrongful convictions is misconduct by prosecutors and police. In Brady v. Maryland, ${ }^{140}$ the Supreme Court held that prosecutors were constitutionally required to disclose exculpatory evidence to the defense, but they often fail to fulfill this duty. According to federal appeals court Judge Alex Kozinski, there is an "epidemic of Brady violations abroad in the land." 141 To deal with the problem of prosecutorial misconduct, Judge Kozinski believes that open file dis-

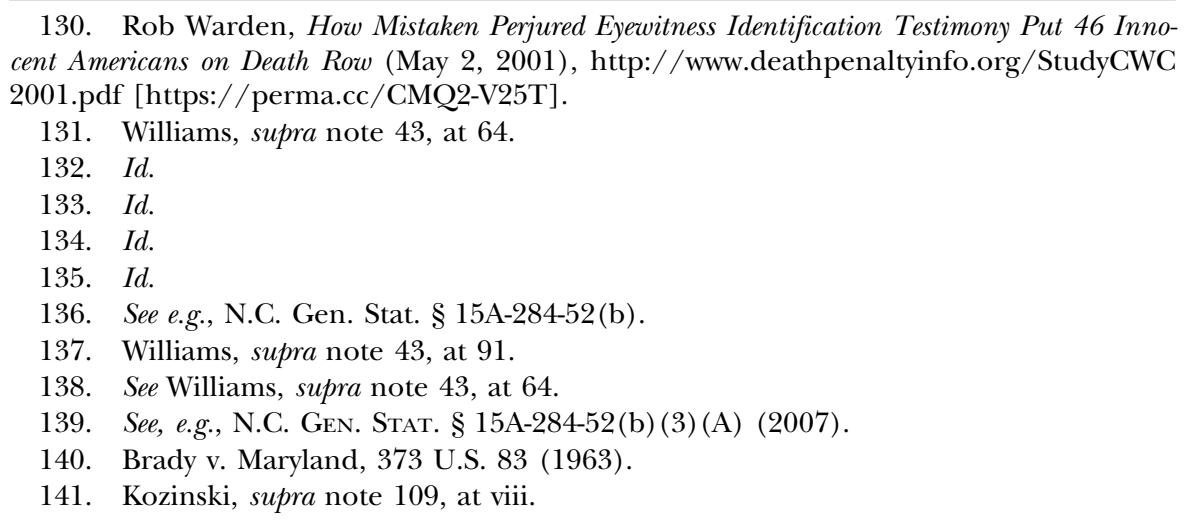


covery $^{142}$ should be required. ${ }^{143}$ Thus, if open file discovery is required, prosecutors would be obligated to disclose any evidence bearing on the crime with which a defendant is being charged, not just exculpatory evidence. ${ }^{144}$ Others have proposed that prosecutors should be disciplined more frequently and harshly when they engage in misconduct. ${ }^{145}$ Separately, but related, police sometimes extract false confessions from suspects. To address that problem, some have opined that police interrogations should be videotaped. ${ }^{146}$

A major impediment to preventing prosecutorial and police misconduct is that there are no incentives for either prosecutors or police officers to play by the rules. Prosecutors and police are rarely prosecuted even when they have been found to have engaged in misconduct. ${ }^{147}$ Although prosecutors can be disciplined by the state bar association, this rarely occurs. ${ }^{148}$ Furthermore, the standard for overturning a conviction based on prosecutorial misconduct or police overreaching is extremely high. The defendant not only has to prove that the violation occurred but also must prove that the evidence resulting from prosecutorial or police misconduct was not harmless. ${ }^{149}$ Most defendants are unable to prove that the misconduct affected the outcome of their case. ${ }^{150}$ Barring a complete overhaul of the disciplinary system governing prosecutors, small reforms are unlikely to curtail these problems.

142. Open file discovery allows defendants to review the prosecution's case files. See, e.g., N.C. GEN. STAT. § 15A-903 (1973).

143. Kozinski, supra note 109 , at xxvi-xxvii.

144. Id.

145. See Williams, supra note 111 , at $1200-01$.

146. Id. at 1202 .

147. For a discussion of the difficulty of holding prosecutor's accountable for misconduct, including a rare instance in Texas in which a prosecutor was prosecuted for misconduct, see Matt Ferner, Prosecutors Are Almost Never Disciplined For Misconduct, Huffington Post (Feb. 11, 2016), http://www.huffingtonpost.com/entry/prosecutor-misconduct-justice_us_56bce00fe4b0c3c55050748a [https://perma.cc/Z5X8-2DR9].

148. See e.g., Martha Bellisle, Despite misconduct, prosecutors rarely face discipline, WASH. Times (Aug. 3, 2015), http://www.washingtontimes.com/news/2015/aug/3/despite-misconduct-prosecutors-rarely-face-discipl/ [https://perma.cc/3JJT-LG39] (according to a study, "The California Bar Association disciplined 1 percent of the prosecutors in 600 cases where misconduct was found.").

149. See United States v. Bagley, 437 U.S. 667, 682 (1985).

150. The Center for Public Integrity found that "in thousands [of] cases, judges labeled prosecutorial behavior inappropriate but allowed the trial to continue or upheld convictions using a doctrine called 'harmless error." "Steve Weinberg, Breaking the Rules: Who Suffers When a Prosecutor is Cited for Misconduct? CTr. For Public Integrity (June 26, 2003), http://www.publicintegrity.org/2003/06/26/5517/breaking-rules [https://per ma.cc/VW3D-Z9K9]. 


\section{iii. Bad Defense Lawyers}

Wrongful convictions in capital cases also occur because of ineffective defense counsel. Defendants who should not be sentenced to death often end up on death row because they were not competently represented. ${ }^{151}$ The obvious remedy would be for jurisdictions to provide greater resources for defense counsel. As Justice Hugo Black observed, " $[\mathrm{t}]$ here can be no equal justice where the kind of trial a [person] gets depends on the amount of money he has." ${ }^{52}$ If more resources were provided for defense counsel, better lawyers would get involved and handle the cases. However, this is unlikely to happen. During a time in which many jurisdictions are strapped for cash and have difficulties providing adequate funding for basic services, such as education and infrastructure repairs, how likely is it that they will have the political courage to propose and defend increases in spending for indigent criminal defendants?

The courts, including the Supreme Court, have been unwilling to heavily regulate the problem of ineffective defense counsel in capital cases. They give great deference to any decision that defense counsel makes no matter how nonsensical it may have been as long as defense counsel can frame it as a strategic decision. ${ }^{153}$ Furthermore, even when defense counsel fails to present obviously mitigating evidence that could have saved a defendant's life, the courts will often refuse to grant relief on the grounds that the defendant suffered no prejudice from the failure of defense counsel to utilize the evidence. ${ }^{154}$

\section{iv. Arbitrariness}

The Supreme Court has labored unsuccessfully to rid the death penalty of arbitrariness through various reforms. In 1972, the Supreme Court invalidated the death penalty because of concerns that it was too arbitrarily imposed. ${ }^{155}$ After reinstating the death penalty in

151. See Bright, supra note 76 (emphasizing that this phenomenon particularly harms poorer defendants).

152. Griffin v. Illinois, 351 U.S. 12, 19 (1956).

153. See, e.g., Cullen v. Pinholster, 131 S. Ct. 1388, 1407 (2011) (explaining that a court is "required not simply to give [the] attorneys the benefit of the doubt, but to affirmatively entertain the range of possible reasons [the petitioner's] counsel may have had for proceeding as they did.")

154. See, e.g., Stephen Henderson, Bad Defense Often Slides in Death Cases, News \& Observer, Jan. 21, 2007, at A1 (describing a study of eighty death penalty cases from Alabama, Georgia, Mississippi, and Virginia regarding the poor quality of legal representation in death penalty cases and the failure of appellate courts to reverse convictions in most of those cases).

155. See Furman v. Georgia, 408 U.S. 238 (1972). 
$1976,{ }^{156}$ the Court has regulated it in an attempt to minimize arbitrariness and limit the penalty to the "worst of the worst." 157 In attempting to limit the arbitrary application of the death penalty, death sentences are automatically appealed. In addition, trials are bifurcated into two separate phases: (1) guilt-innocence and (2) punishment. ${ }^{158}$ In the second phase, the Court has mandated a broad right to individualized sentencing to permit capital defendants to invoke any relevant grounds supporting a non-death sentence. ${ }^{159}$ The Court has also limited the offenses punishable by death by exempting non-homicidal crimes. ${ }^{160}$ Further, the Court has categorically excluded certain vulnerable groups, such as juveniles ${ }^{161}$ and intellectually disabled offenders, ${ }^{162}$ from the penalty's reach. Notwithstanding these changes, the death penalty continues to be fraught with arbitrariness. Factors such as geography, race, resources, and quality of defense counsel continue to matter more than the heinousness of the crime in determining whether an inmate is sentenced to death. ${ }^{163}$

The Court can continue its current attempt to regulate the death penalty instead of abolishing it outright. As discussed earlier, ${ }^{164}$ the Supreme Court has attempted to reform the death penalty on multiple occasions. But, these reforms have not produced a fairer death penalty. There are still serious racial disparities despite Batson; ${ }^{165}$ the death penalty is still not confined to the worst offenders despite the Supreme Court's attempts to do so; ${ }^{166}$ and capital defendants are still frequently represented by incompetent defense counsel despite the Court's decision in Strickland. ${ }^{167}$

156. See Gregg v. Georgia, 428 U.S. 153 (1976).

157. See, e.g., Kansas v. Marsh, 548 U.S. 163, 206 (2006) (Souter, J., dissenting); Godfrey v. Georgia, 446 U.S. 420, 432-33 (1980) ("[I]t is of vital importance to the defendant and to the community that any decision to impose the death sentence be, and appear to be, based on reason rather than caprice or emotion." (inner quotations omitted)).

158. See, e.g., Tennard v. Dretke, 542 U.S. 274, 276-77 (2004) (referring to the second phase as the "penalty phase" after a jury conviction).

159. See id. at 284-85 (2004).

160. See, e.g., Kennedy v. Louisiana, 554 U.S. 407 (2008) (prohibiting the death penalty for the rape of a child); Coker v. Georgia, 433 U.S. 584 (1977) (prohibiting the death penalty for the rape of an adult woman).

161. See Roper v. Simmons, 543 U.S. 551 (2005).

162. See Atkins v. Virginia, 536 U.S. 304 (2002).

163. See Glossip v. Gross, 135 S. Ct. 2726, 2760 (2015) (Breyer, J., dissenting).

164. See supra Part II.

165. Batson v. Kentucky, 476 U.S. 79 (1986). See supra Part I.B.

166. See Glossip, 135 S. Ct. at 2760 (Breyer, J., dissenting).

167. Id. at 2761. 
Any future effort to reform the death penalty is similarly unlikely to succeed. The failure of the aforementioned reforms will likely lead to a continued marginalization of the death penalty. Although death penalty statutes may remain on the books in several states, death sentences will rarely be imposed in the vast majority of states. ${ }^{168} \mathrm{In}$ these states, despite the dwindling number of executions, the death penalty will continue to be "fraught with arbitrariness, discrimination, caprice, and mistake."169 Individuals who do not deserve to die will continue to be sentenced to death and executed. There is also the possibility that an individual who is completely innocent will be executed.

Taking these pervasive structural problems of the criminal justice system into consideration, the Supreme Court should finally admit that Justice Blackmun was right in 1994 when he said that "no combination of procedural rules or substantive regulations ever can save the death penalty from its inherent constitutional deficiencies" 170 and abolish the death penalty.

\section{B. Abolition}

There are several grounds upon which the Supreme Court could declare the death penalty unconstitutional. The Court would not have to create new constitutional doctrines in order to do so. The Court could rely upon existing death penalty jurisprudence that it has developed since 1976.

\section{i. Equal Protection}

The strongest-but least likely—way the Court could invalidate the death penalty is by using the Equal Protection Clause of the Fourteenth Amendment. The Equal Protection Clause generally prohibits the government from discriminating against its citizens without a legitimate reason for doing so. In the event that a law discriminates on the basis of race, the government must put forth a compelling reason to

168. For instance, despite having the death penalty on the books, New Hampshire has carried out zero executions since 1976; Colorado has carried out one; Wyoming, one; United States Military, zero. Pennsylvania, which has 175 death row inmates, has carried out three executions. California, which has the largest death row population, 741, has executed only thirteen inmates since 1976 and none since 2006. State by State Database, Death Penalty Info. Ctr., http://www.deathpenaltyinfo.org/state_by_state (last visited Dec. 16, 2016) [https://perma.cc/3EH8-PEWV].

169. Callins v. Collins, 510 U.S. 1141, 1144 (1994) (Blackmun, J., dissenting).

170. Id. at 1145 . 
justify the discrimination. ${ }^{171}$ If the government fails to do so, the law violates equal protection and will be struck down. ${ }^{172}$ To prove an equal protection violation, it is not necessary that a law discriminate explicitly on the basis of race. ${ }^{173}$ An equal protection violation also occurs if the law is applied in a discriminatory manner. ${ }^{174}$ However, in order to trigger this "strict scrutiny," proof of a racially discriminatory purpose is usually required. ${ }^{175}$ The Supreme Court has not allowed equal protection violations to be proven only with evidence that a law disproportionately burdens members of a particular racial group. ${ }^{176}$

For much of the nation's history, death penalty statutes were explicitly racist and were applied in a racially discriminatory manner. ${ }^{177}$ Blacks could be-and were-executed for crimes that whites could not be. ${ }^{178}$ Blacks often were also executed more gruesomely than whites. ${ }^{179}$ During the modern era of capital punishment, death penalty statutes are no longer explicitly discriminatory. In fact, as discussed earlier, there have been measures implemented to ensure that racial discrimination does not infect the decision-making process in death penalty cases. ${ }^{180}$ However, racial disparities in the administration of the death penalty persist. African-Americans are sentenced to death at a higher ratio than warranted given their percentage of the population. ${ }^{181}$ In addition, killers of whites are significantly more likely to be sentenced to death than killers of African-Americans. ${ }^{182}$ Furthermore, discriminatory jury selection continues to occur in capital cases despite the Supreme Court's attempt to remedy the problem. ${ }^{183}$ Because African-Americans are not treated equally when the death penalty is sought and carried out, a claim could be made that

\footnotetext{
171. See, e.g., Gratz v. Bollinger, 539 U.S. 244, 270 (2003).

172. Id.

173. See Washington v. Davis, 426 U.S. 229, 241 (1976).

174. Id.

175. Id. at 240 ("[T] he invidious quality of a law claimed to be racially discriminatory must ultimately be traced to a racially discriminatory purpose.").

176. Id. at 239 ("But our cases have not embraced the proposition that a law or other official act, without regard to whether it reflects a racially discriminatory purpose, is unconstitutional solely because it has a racially disproportionate impact." (emphasis in original)).

177. See Steiker \& Steiker, supra note 27, at 248-253.

178. Id. at 248.

179. Id.

180. See, e.g., 18 U.S.C. \$ 3593(f) (2013).

181. See U.S. Census Bureau, supra note 28; Race, Death Penalty Info. Ctr., supra note 30 .

182. See Race, Death Penalty Info. Ctr., supra note 30; Uniform Crime Report, supra note 32.

183. See Edeleman, supra note 50.
} 
the death penalty violates equal protection and is therefore unconstitutional.

The requirement of proving a discriminatory purpose would be one significant hurdle in declaring the death penalty unconstitutional on Fourteenth Amendment grounds. Warren McCleskey produced statistical evidence to support his claim that because he was a black man accused of killing a white victim, he was more likely to be sentenced to death and thus a violation of equal protection had occurred. ${ }^{184}$ However, he was not able to produce evidence that when the Georgia legislature enacted its death penalty statute, it did so with a racially discriminatory purpose. ${ }^{185} \mathrm{He}$ also could not produce evidence that the decisionmakers in his case-either the judge, jury, or prosecutor-purposely discriminated against him. ${ }^{186}$ The Court held that without such proof, his equal protection claim failed. ${ }^{187}$

Should the Supreme Court accept statistics of the racially discriminatory impact of capital punishment it would require the Court to overrule its previous decisions disallowing evidence of discriminatory impact as proof of an equal protection violation. ${ }^{188}$ The Court is not likely to begin this practice because of the impact such a decision would have-not only on the death penalty and the criminal justice system-in other areas of American life. ${ }^{189}$

The Court, however, would not have to go this far in order to find that the current administration of the death penalty violates equal protection. Since 1976, the Court has said that "death is different," 190 which justifies applying different standards in death penalty cases. ${ }^{191}$

\footnotetext{
184. McCleskey v. Kemp, 481 U.S. 279, 288 (1987).

185. Id. at 298-99.

186. Id. at 292-93.

187. Id. at 299.

188. See e.g., Washington v. Davis, 426 U.S. 229 (1976).

189. For instance, in McCleskey, the Court expressed its concern that "if we accept McCleskey's claim that racial bias has impermissibly tainted the capital sentencing decision, we could soon be faced with similar claims as to other types of penalty." McCleskey, $481 \mathrm{U}$. S. at 315 (1987).

190. See Woodson v. North Carolina, 428 U.S. 280, 303-04 (1976) ("death is a punishment different from all other sanctions in kind rather than degree.") (citing Furman v. Georgia, 408 U.S. 238, 286-291 (1976)) (Brennan, J., concurring).

191. For instance, the Court requires that in capital cases, the sentencer be empowered to take into account all mitigating circumstances, see Lockett v. Ohio, 438 U.S. 586, 604 (1978); prohibits death as a mandatory punishment for murder, see Woodson, 428 U.S. 305; requires that the sentencer not be given unguided discretion, see Furman, 408 U.S. 238 (1972); that the accused receive a judicial evaluation of his claim of insanity before the sentence can be executed, see Ford v. Wainwright, 477 U.S. 399, 410-11 1986); that the accused receive a judicial evaluation of his claim of intellectual disability, see Hall v. Florida, 134 S. Ct. 1986, 2001 (2014); that the death penalty cannot be imposed for rape, see Coker
} 
The Court has also allowed statistical evidence to prove a claim of discrimination in jury selection, a claim intertwined with capital punishment. ${ }^{192}$ Thus, by applying its "death is different" jurisprudence, the Court could accept statistics as proof of discriminatory purpose in death penalty cases only, while leaving intact its previous decisions rejecting similar evidence as proof of equal protection violations in other cases.

Although the Court could use its current jurisprudence to find that the death penalty violates equal protection, it is unlikely to do so. Since at least the 1960's, litigants have sought to engage the court in issues concerning the racial application of the death penalty. ${ }^{193}$ Despite these efforts, the Court has given the issue of race little attention. ${ }^{194}$ For instance, the death penalty had always been imposed more frequently in cases involving black defendants accused of rape and especially when these defendants were accused of raping white women. ${ }^{195}$ The NAACP Legal Defense Fund ("LDF") tried unsuccessfully to convince the Court to accept certiorari in cases where black defendants had been accused of raping white women. ${ }^{196}$ The Court consistently declined to do so. ${ }^{197}$

The Court did eventually grant certiorari on the issue of whether the death penalty could be imposed for rape. The case it accepted involved a white defendant and white victim. ${ }^{198}$ Briefs filed with the Court, including briefs by the LDF and the National Organization for Women, still urged the Court to strike down the practice because of the disproportionate use of the death penalty in rape cases against black men. ${ }^{199}$ However, in its opinion finding the death penalty for rape unconstitutional, the Court did not address the issue of race. ${ }^{200}$

v. Georgia, 433 U.S. 584, 592 (1977); nor for ordinary murder, see Godfrey v. Georgia, 446 U.S. 420, 433 (1980).

192. See Batson v. Kentucky, 476 U.S. 79, 93-94 (1986).

193. See Steiker \& Steiker, supra note 27, at 253-77 (detailing attempts from litigants such as the NAACP Legal Defense Fund to convince the Court to accept certiorari and address some of the racial issues surrounding the death penalty. The Court avoided the issue of race and decided the cases on other grounds).

194. Id. at 253.

195. Id. at $273-77$.

196. Id. at 276 .

197. Id.

198. Id. at 280.

199. See Steiker \& Steiker, supra note 27 at 274.

200. See Coker v. Georgia, 433 U.S. 584 (1977). Even Justice Marshall avoided the issue of race in his concurring opinion. Id. at 600-01 (Marshall, J., concurring). 
The Court instead relied on the Eighth Amendment in striking down the death penalty for rape. ${ }^{201}$

Similarly, briefs filed with the Court in Furman v. Georgia ${ }^{202}$ urged it to strike down the death penalty because of its racially discriminatory application. ${ }^{203}$ The Court did strike down the death penalty in Furman, however, the decision was not based on race. ${ }^{204}$ The Court also ignored the issue of race when it re-imposed the death penalty in Gregg v. Georgia ${ }^{205}$ despite the fact that the briefs filed with the Court had discussed the issue at length. ${ }^{206}$

More recently, Justice Sotomayor has urged the Court to have an honest discussion about race when she wrote:

The refusal to accept the stark reality that race matters is regrettable. The way to stop discrimination on the basis of race is to speak openly and candidly on the subject of race, and to apply the Constitution with eyes open to the unfortunate effects of centuries of racial discrimination. ${ }^{207}$

However, there is no evidence to suggest that the Court is willing to acknowledge the role that race plays in the imposition of the death penalty. Justice Breyer, for instance, did not specifically list race as a reason for the Court to revisit the death penalty and he only briefly mentioned the racial disparities in his Glossip dissent. ${ }^{208}$ Based on the Court's longstanding reluctance to discuss the issue of race and capital punishment, there is no reason to be optimistic that will change in the near future. If the Court decides to strike down the death penalty it is likely to do so as the Constitutional Court of South Africa did, not on explicit racial grounds, but with race in the backdrop of its decision. ${ }^{209}$

\footnotetext{
201. Id. at 592 .

202. Furman v. Georgia, 408 U.S. 238 (1972).

203. See Steiker \& Steiker, supra note 27 , at 263-65.

204. Id. at 265-67.

205. Gregg v. Georgia, 428 U.S. 153.

206. Steiker \& Steiker, supra note 27, at 269-72.

207. Schuette v. Coalition to Defend Affirmative Action, 134 S. Ct. 1623, 1676 (2014).

208. Justice Breyer stated that the Court should reconsider its holding in Gregg for three reasons: (1) serious unreliability of the death penalty; (2) arbitrariness in application; and (3) unconscionably long delays that undermine the death penalty's penological purpose. See Glossip v. Gross, 135 S. Ct. 2726, 2755-56 (2015) (Breyer, J., dissenting). In one paragraph of his dissent, he cites studies indicating that individuals accused of murdering whites are more likely to receive the death penalty as proof of the arbitrary application of the death penalty. Id. at 2760-61.

209. Although the South African Constitutional Court based its ruling abolishing the death penalty on the right to life provision of its new constitution, the fact

[t]hat the Constitutional Court chose the death penalty issue for its first major ruling underscored the importance of the issue in a country where for decades
} 


\section{ii. Cruel and Unusual Punishment}

If the Court is to strike down the death penalty, the Eighth Amendment's prohibition on cruel and unusual punishment provides the best vehicle. In its past decisions, the Court has acknowledged that the death penalty would be unconstitutional if "inflicted in an arbitrary and capricious manner." 210 To strike down the death penalty, the Court could rely upon research that strongly "suggests that the death penalty is imposed arbitrarily." 211 The first indication of an arbitrary death penalty lies in the high number of death row inmates whom have been wrongly sentenced to death. ${ }^{212}$ Second, as discussed earlier, there is an abundance of evidence that the factors such as race, geography, gender, and resources play a big role in determining who is sentenced to death. ${ }^{213}$ Finally, in accepting that the egregiousness of the crime largely does not correlate with a death sentence, ${ }^{214}$ the Court would have to acknowledge that its attempts to limit the death penalty to the "worst of the worst" have failed and there is nothing that it can do going forward to succeed in this endeavor.

The Court has also held that the death penalty would be cruel and unusual punishment in the event that it failed to serve a penological purpose. ${ }^{215}$ A strong argument can be made that the current administration of the death penalty fails to serve a penological purpose. The argument that the death penalty serves as a deterrent has been long debated. ${ }^{216}$ Scholars generally agree that the deterrent value of the death penalty is dependent upon sentencing that is frequent, swift, and provides some level of certainty as to which offenders will

execution was used not just as a weapon against common crime, but as a means of terror in enforcing the system of racial separation known as apartheid.

Howard W. French, South Africa's Supreme Court Abolishes Death Penalty, N.Y. Times (June 7, 1995), http://www.nytimes.com/1995/06/07/world/south-africa-s-supremecourt-abolishes-death-penalty.html [https://perma.cc/N6XF-WF54].

210. Gregg, 428 U.S. at 188.

211. Glossip, 135 S. Ct. at 2762 (Breyer, J., dissenting).

212. Id. at 2758 .

213. Id. at 2760 .

214. Id. at 2762 .

215. The Court has said that if the death penalty doesn't serve the goals of either deterrence or retribution, "It is nothing more than the purposeless and needless imposition of pain and suffering and hence an unconstitutional punishment." Edmund v. Florida, 458 U.S. 782, 798 (1982) (inner quotations omitted). See also Gregg, 428 U.S. at 183 (" $[\mathrm{S}]$ anction imposed cannot be so totally without penological justification that it results in the gratuitous infliction of suffering.").

216. See, e.g., Jeffrey Fagan, Death and Deterrence Redux: Science, Law and Causal Reasoning on Capital Punishment, 4 Ohio St. J. of Crim. L. 255-62 (2006). 
receive the punishment. ${ }^{217}$ The deterrence rationale, however, is undermined by the fact that only a small number of murderers are actually sentenced to death. ${ }^{218}$ The deterrence rationale is further undermined by the long delays in carrying out the death penalty. An individual contemplating whether to commit a capital crime is not likely to be deterred by the prospect of being executed many years later.

Retribution is another acceptable penological purpose that the death penalty could serve. ${ }^{219}$ Many argue that the death penalty should be retained as a punishment for the "worst of the worst." However, the retributive justification is undermined by the fact that death sentences are frequently not meted out to the most egregious killers. ${ }^{220}$ The retribution theory does not comport with evidence indicating that the individuals frequently sentenced to death are not the worst killers in society and, therefore, are not as deserving of death. The long delays ${ }^{221}$ in carrying out the death penalty further undermine the retributive rationale for the death penalty.

The death penalty does, however, serve one penological purpose-incapacitation. A killer who is executed can no longer kill again. However, it is not necessary to execute the offender in order to prevent him from killing again. A sentence of life without parole is adequate if the goal is to protect society. As the Catholic Church acknowledges, the execution of a killer is not necessary for public safety: "As a result of steady improvements in the organization of the penal system, such cases [executions to protect society] are very rare, if prac-

217. See Raymond Paternoster, How Much Do We Really Know About Criminal Deterrence?, 100 J. Crim. L. \& Criminology 765, 783-84 (2010).

218. See Arbitrariness, Death Penalty Info. CTR., http://www.deathpenaltyinfo.org/arbitrariness (last visited Jan. 17, 2017) [https://perma.cc/265G-2QQG] ("[L] ess than $2 \%$ of known murderers are sentenced to death.").

219. See Gregg, 428 U.S. at 183.

220. For example, Justice Breyer questioned the randomness of death penalty sentences meted out for various crimes in his Glossip dissent:

I see discrepancies for which I can find no rational explanations . . . Why does one defendant who committed a single-victim murder receive the death penalty . . . while another defendant does not, despite having kidnapped, raped, and murdered a young mother while leaving her infant baby to die at the scene of the crime . . . For that matter, why does one defendant who participated in a singlevictim murder-for-hire scheme (plus an after-the-fact robbery) receive the death penalty, while another defendant does not, despite having stabbed his wife 60 times and killed his 6-year-old daughter and 3-year-old son while they slept?

Glossip, 135 S. Ct. at 2763 (Breyer, J., dissenting).

221. Id. at 2769 ("[E]xecutions occur, on average, after nearly two decades on death row."). 
tically nonexistent." ${ }^{222}$ In light of this reality, the death penalty is the type of gratuitous punishment that the Eighth Amendment does not allow. The Court could use the fact that the death penalty fails to serve any penological purpose as grounds for holding the death penalty unconstitutional. The Court did just that in both Roper v. Simmons ${ }^{223}$ (holding that the Eighth Amendment prohibited the execution of juveniles) and in Atkins v. Virginia ${ }^{224}$ (holding that the Eighth Amendment prohibited the execution of intellectually disabled inmates).

The Eighth Amendment also prohibits excessive punishments. The Court has used its "evolving standards of decency" doctrine to determine whether certain punishments are excessive. ${ }^{225}$ The "evolving standards of decency" doctrine is a recognition "that the words of the [Eighth] Amendment are not precise and their scope is not static." 226 According to the Court, "[t]he Amendment must draw its meaning from the evolving standards of decency that mark the progress of a maturing society." ${ }^{227}$ In determining whether a particular punishment is in conflict with evolving standards of decency, the Court looks to whether there is objective evidence of a national consensus condemning the punishment. ${ }^{228}$ In Roper $v$. Simmons, ${ }^{229}$ the Court applied its evolving standards of decency doctrine and determined there was a national consensus against executing juveniles. ${ }^{230}$ The Court pointed to several objective indicia of a national consensus against executing juveniles. First, the Court considered the fact that, at the time of its decision, thirty states prohibited the execution of juveniles. ${ }^{231}$ Second, even in the twenty states that allowed juveniles to be executed, the practice was infrequent. ${ }^{232}$ The Court also indicated that, in determining whether a national consensus existed, "[i]t is not so much the number of these States [that prohibit juvenile executions] that is significant, but the consistency of the direction of

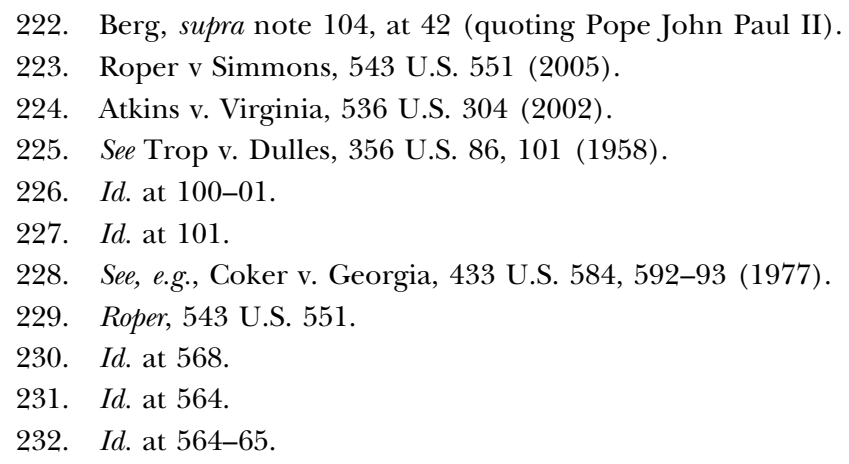


change." ${ }^{233}$ In this regard, the Court found significant the fact that no state had reinstated the death penalty for juveniles. ${ }^{234}$

The Court in Roper pointed to other evidence of the consensus against executing juveniles. The Court has long considered the opinions of the civilized nations of the world in determining whether a punishment comports with the evolving standards of decency. ${ }^{235}$ In Roper, the Court pointed out "the stark reality that the United States is the only country in the world that continues to give official sanction of the juvenile death penalty." 236 The Court emphasized that the United Nations Convention on the Rights of the Child contained an express prohibition on capital punishment for crimes committed by juveniles under eighteen and that this Convention was further evidence of a broad international consensus against executing juveniles. ${ }^{237}$

The Court used similar evidence of a national consensus in holding that the Eighth Amendment prohibited the death penalty for intellectually disabled inmates. ${ }^{238}$ At the time of its Atkins decision, there were also over thirty states that prohibited the death penalty for intellectually disabled inmates; ${ }^{239}$ the movement was strongly in the direction away from allowing such executions; ${ }^{240}$ the practice was rare; ${ }^{241}$ and there was a consensus among professional and religious organizations that intellectually disabled inmates should not be executed. ${ }^{242}$

The Court's evolving standards of decency test could lead to the conclusion that the death penalty violates the Eighth Amendment. Although thirty-one states, the federal government, and the U.S. military still authorize the death penalty, ${ }^{243}$ this figure is misleading. Four of these states have Governor-imposed moratoriums on executions. ${ }^{244}$ Two other states and the U.S. military have not executed anyone dur-

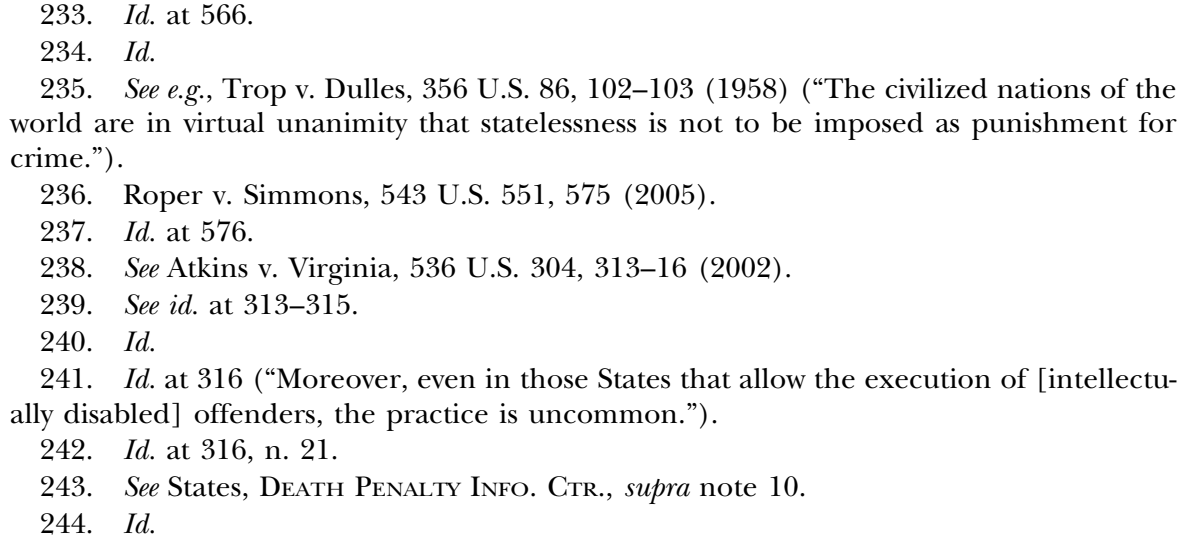


ing the modern era of capital punishment. ${ }^{245}$ Nine other states and the federal government have not carried out an execution in at least ten years. ${ }^{246}$ Several other states have small death rows and the death penalty is rarely sought in these states. ${ }^{247}$ Therefore, more than half of the states have either formally abolished the death penalty or have done so in practice.

Only a small number of states continue to sentence inmates to death and carry out executions. ${ }^{248}$ However, even in these states, the use of the death penalty is in decline. ${ }^{249}$ Furthermore, even in the small number of active death penalty states, death sentences are typically meted out in only a few counties within the state. ${ }^{250}$ Most importantly, the Court in its recent Eighth Amendment decisions has deemphasized the sheer number of states that authorize a challenged practice and instead emphasized the direction of change. ${ }^{251}$ The movement is clearly in the direction of abolition. Numerous states have abolished the death penalty during the last ten years. ${ }^{252}$ Voters in California, however, refused to abolish the death penalty in the November 2016 election. ${ }^{253}$ Despite this setback, the Court's criteria still definitively points toward abolition.

245. Kansas and New Hampshire have not executed a defendant since before 1976, despite having the death penalty available. See Jurisdictions with no recent executions, Death Penalty Info. CTR., http://www.deathpenaltyinfo.org/jurisdictions-no-recent-executions (last visited Jan. 17, 2017) [https://perma.cc/A3BE-SLJJ].

246. Id. (listing Arkansas, California, Colorado, Montana, Nevada, North Carolina, Oregon, Pennsylvania, and Wyoming).

247. Idaho, for example, currently has only nine death row inmates. Death Row Inmates by State, Death Penalty Info. Ctr. (July 1, 2016), http://www.deathpenaltyinfo .org/death-row-inmates-state-and-size-death-row-year?scid=9\&did=188 [https://perma.cc/ R3V2-77XN].

248. The more active death penalty states include Texas, Florida, Missouri, Georgia, Oklahoma, Virginia, and California. While California continues to sentence a large number of inmates to death, it has not carried out an execution in more than ten years. For information on death sentences, see By Year, Death Penalty Information Ctr., supra note 4. For information on executions, see Executions by State, Death Penalty Information CTR., supra note 71.

249. See Williams, supra note 6.

250. See Executions by County, Death Penalty Info. Ctr. (Jan. 1, 2011) http://www .deathpenaltyinfo.org/executions-county [https://perma.cc/TZ6R-K99U] (“[Fifteen] counties accounted for $30 \%$ of the executions in the U.S. between 1976 and January 1, 2013.”).

251. See Atkins v. Virginia, 536 U.S. 304, 315 (2002) ("It is not so much the number of these states that is significant, but the consistency of the direction of change.").

252. For information on states that have abolished the death penalty, see States, DeATH Penalty Info. Ctr., supra note 10.

253. For analysis of the vote, see McPhate, supra note 10. 
Additional objective evidence of the movement away from the death penalty is abundant. First, in striking down the death penalty for juveniles and intellectually disabled inmates, the Court emphasized the fact that the practices had become so rare. ${ }^{254}$ As discussed earlier, ${ }^{255}$ there has been a significant decline in death sentences over the last fifteen years. ${ }^{256}$ Second, several respected professional and religious organizations support the abolition of the death penalty or imposing a moratorium on executions. Most notably, the American Law Institute has withdrawn the death penalty provision of the Model Penal Code. ${ }^{257}$ Third, several former and present Justices have publicly called attention to the problems in the administration of the death penalty. ${ }^{258}$ Fourth, in its Eighth Amendment decisions, the Court has considered the opinions of the international community with respect to a particular practice. ${ }^{259}$ In this regard, most nations in the world community have abolished the death penalty either by law or in practice. ${ }^{260}$ The United States' use of the death penalty has isolated it from the international community. For instance, many nations will not extradite criminal suspects to the United States without an assurance that the suspect will not be sentenced to death. ${ }^{261}$ In addition, several nations have challenged the United States' attempt to execute their citizens. ${ }^{262}$

The Court has also indicated that although evidence of a national consensus is important, it does not wholly determine whether a particular practice violates the Eighth Amendment. Rather, the Court has stated that

\footnotetext{
254. Atkins, 536 U.S. at 316.

255. See supra Part I.

256. See By Year, Death Penalty Info. Ctr., supra note 4.

257. See Carol S. Steiker \& Jordan M. Steiker, No More Tinkering: The American Law Institute and the Death Penalty Provisions of the Model Penal Code, 89 Tex. L. REv. 353, 359-360 (2010).

258. See Jeffries, supra note 64; Callins v. Collins, 510 U.S. 1141, 1145 (1994) (Blackmun, J., dissenting); Baze v. Rees, 553 U.S. 35, 81 (2008) (Stevens, J., concurring).

259. See e.g., Roper v. Simmons, 543 U.S. 551, 575-76 (2005).

260. According to Amnesty International, approximately two thirds of the countries around the world have abolished the death penalty. See Death Sentences and Executions Report 2015, Amnesty InT'L (Apr. 6, 2016), https://www.amnesty.org/en/what-we-do/ death-penalty/ [https://perma.cc/SW5G-JEKX].

261. See, e.g., Soering v. United Kingdom, 161 Eur. Ct. H.R. (ser. A) (1989) (holding that United Kingdom could not extradite murder suspect to the United States because of death row phenomenon).

262. See Avena and Other Mexican Nationals (Mex. v. U. S.), Judgment, 2004 I.C.J. 1 (Mar. 31) (holding that United States violated international law by sentencing fifty-four Mexican nationals to death without providing them with notification of their rights to communicate with their consulates prior to trial).
} 
the Constitution contemplates that in the end our own judgment will be brought to bear on the question of the acceptability of the death penalty under the Eighth Amendment . . . . Thus, in cases involving a consensus, our own judgment is 'brought to bear,' [citation omitted] by asking whether there is reason to disagree with the judgment reached by the citizenry and its legislators. ${ }^{263}$

Given the risk of wrongful convictions and executions, the Court would have no reason to disagree with the public's movement away from capital punishment.

\section{Objections to Abolition}

Three major objections are likely to be made to the Supreme Court invalidating the death penalty. The first, and probably strongest, objection will be that the text of the Constitution allows the death penalty to be imposed. ${ }^{264}$ As Justice Scalia argues, "[i]t is impossible to hold unconstitutional that which the Constitution explicitly contemplates." ${ }^{265}$ In support of his position, Justice Scalia specifically refers to the Fifth Amendment which provides that " $[\mathrm{n}]$ o person shall be held to answer for a capital ... crime, unless on a presentment or indictment of a Grand Jury," and which also provides that no person shall be "deprived of life . . . without due process of law." 266 These two provisions in the Constitution, it will be argued, make it clear that the Framers did not intend to prohibit capital punishment when it enacted the Eighth Amendment. In Scalia's view of the Eighth Amendment, it was enacted only to prohibit those punishments that added "terror, pain, or disgrace" to an otherwise permissible capital sentence. ${ }^{267}$

There are a couple of major flaws in the argument that the death penalty is constitutional because of the Fifth Amendment. First, the Fifth Amendment does not confer power onto the state. Rather it limits the power of the state by requiring certain procedural safeguards. As Justice Brennan explained, the "amendment does not, after all, declare the right of the Congress to punish capitally shall be inviolable; it merely requires that when and if death is a possible punishment, the defendant shall enjoy certain procedural safeguards, such as indict-

263. Atkins v. Virginia, 536 U.S. 304, 312-13 (2002).

264. See Gregg v. Georgia, 428 U.S. 153, 177 (1976) ("It is apparent from the text of the Constitution itself that the existence of capital punishment was accepted by the Framers.").

265. Glossip v. Gross, 135 S. Ct. 2726, 2747 (2015) (Scalia, J., dissenting) (emphasis in original).

266. Id.

267. Id. 
ment by grand jury and, of course, due process." 268 Second, those who use the Fifth Amendment to argue that the death penalty is constitutional fail to explain why it should trump the Eighth Amendment. For instance, the double jeopardy provision of the Fifth Amendment seems to contemplate the taking of limbs as punishment: “ $[\mathrm{N}]$ or shall any person be subject for the same offense to be twice put in jeopardy of life or limb." 269 Wouldn't the Eighth Amendment prohibit the taking of limbs even though it is contemplated in the Fifth Amendment?

How the Court resolves the issue of whether the text of the Constitution constrains it from abolishing the death penalty will also depend on whether a majority of the Court views the Constitution as a "living document" or whether a majority believes that strict adherence to the text of the Constitution is required. ${ }^{270}$ Proponents of a "living constitution" believe that it "evolves, changes over time, and adapts to new circumstances, without being formally amended." 271 They believe that the world has changed in ways that the Framers could not have foreseen and therefore the Constitution cannot be restricted to the world that the Framers faced. ${ }^{272}$ On the other hand, those who believe in strict adherence to the text of the Constitution, "originalists," believe that the text of the Constitution should be given the meaning that it bore when it was adopted. ${ }^{273}$ According to originalists, the Constitution is supposed to be an embodiment of our most fundamental principles. ${ }^{274}$ Public opinion, they say, will change but our basic constitutional principles must remain constant. ${ }^{275}$ Otherwise, an originalist would ask, why have a Constitution at all?276 An originalist believes that if the Constitution changes at all, it should be through the people by way of a constitutional amendment as the Constitution provides. ${ }^{277}$

The Supreme Court has confronted the issue of whether the Constitution is an evolving document and a majority of the Supreme

268. William J. Brennan, Jr., Constitutional Adjudication and the Death Penalty: A View from the Court, 100 Harv. L. Rev. 313, 323-24 (1986).

269. U.S. Const. amend. V.

270. See, e.g., David A. Strauss, The Living Constitution (2010), http://www.law.uchica go.edu/alumni/magazine/fall10/strauss [https://perma.cc/M4RZ-4L26].

271. Id.

272. $I d$.

273. Id

274. Id

275. Id.

276. See Strauss, supra note 270.

277. See Justice Antonin Scalia, Remarks at Woodrow Wilson Int'l Ctr. for Scholars (Mar. 14, 2005), http://www.bc.edu/content/dam/files/centers/boisi/pdf/Symposia/ Symposia\%202010-2011/Constitutional_Interpretation_Scalia.pdf [https://perma.cc/7M R7-ZXND]. 
Court has come down squarely on the "living constitution" side. The Court in N.L.R.B. v. Noel Canning, ${ }^{278}$ in deciding the limits to the President's recess appointments power under the Constitution, declared that:

The Founders knew they were writing a document designed to apply to ever-changing circumstances over centuries. After all, a Constitution is 'intended to endure for ages to come' and must adapt itself to a future that can only be 'seen dimly,' if at all. [citation omitted] We therefore think the Framers likely did intend the Clause to apply to a new circumstance that so clearly falls within its essential purposes, where doing so is consistent with the Clause's language. ${ }^{279}$

In other decisions, the Court has made clear that it believes that the interpretation of the Constitution should evolve over time. ${ }^{280}$ For instance, the text of the Constitution does not address discrimination based on sexual orientation-an uncontemplated issue when the Fourteenth Amendment was enacted-yet the Court has decided that the Constitution protects the right of gays and lesbians to marry. ${ }^{281}$

There are other reasons for rejecting the Framers' view of the constitutionality of the death penalty. How the death penalty is administered today is very different from the death penalty that the Framers administered. There is no evidence to suggest that the Framers were aware that mistakes were being made in sentencing defendants to death. Today, we have been made well aware of the flaws in the administration of the death penalty. The Framers were also likely not aware of the arbitrary application of the death penalty. At common law, for instance, all felonies were punishable by death. ${ }^{282}$ Today we are well aware that receiving the death penalty is about as arbitrary as being struck by lightning. ${ }^{283}$ Furthermore, the Framers did not have to deal with the long delays in carrying out executions that typically

278. N.L.R.B. v. Noel Canning, 134 S. Ct. 2550 (2014).

279. Id. at 2564-65.

280. See, e.g., Obergefell v. Hodges, 135 S. Ct. 2584, 2598 (2015) (in deciding whether the Fourteenth Amendment requires states to permit same sex couples to marry the Court stated " $[\mathrm{h}]$ istory and tradition guide and discipline this inquiry but do not set its outer boundaries.").

281. See id. at 2628 (Scalia, J., dissenting) (" $[\mathrm{I}] \mathrm{t}$ is unquestionable that the people who ratified [the Fourteenth Amendment] did not understand it to prohibit a practice that remained both universal and uncontroversial in the years after ratification.").

282. See Woodson v. North Carolina, 428 U.S. 280, 289 (1976).

283. See Furman v. Georgia, 408 U.S. 238, 309 (1972) (Stewart, J., concurring) ("These death sentences are cruel and unusual in the same way that being struck by lightening is cruel and unusual."). 
occur today and the suffering that accompanies these long delays. ${ }^{284}$ Finally, the death penalty was a widely acceptable practice around the world when the Constitution was enacted. ${ }^{285}$ Presently, a majority of the international community no longer views the death penalty as an acceptable punishment. ${ }^{286}$ Therefore, these changing circumstances warrant a different interpretation of the Eighth Amendment from that of the Framers. An interpretation by the Court that the Eighth Amendment now prohibits capital punishment would be consistent with the Amendment's essential purposes and text.

Justice Scalia articulated the second objection to the Supreme Court abolishing capital punishment. The death penalty is an issue that should be left to the American people to decide:

The American people have determined that the good to be derived from capital punishment-in deterrence, and perhaps most of all in the meting out of condign justice for horrible crimes-outweighs the risk of error. It is no proper part of the business of this Court, or of its Justices, to second guess that judgment, much less to impugn it before the world, and less still to frustrate it by imposing judicially invented obstacles to its execution. ${ }^{287}$

Thus, according to Justice Scalia, individual states should be free to decide whether to retain or abolish capital punishment and they should even have autonomy in carrying it out with almost no interference from the Court.

284. See Knight v. Florida, 528 U.S. 990, 995 (1999) (Breyer, J., dissenting) ("Nor can one justify lengthy delays by reference to constitutional tradition, for our Constitution was written at a time when delay between sentencing and execution could be measured in days or weeks, not decades.").

285. See, e.g., Stuart Banner, Death Penalty: An American History 5 (2002).

286. The vast majority of nations have abolished the death penalty. For a list of nations that have abolished the death penalty, see Abolitionist and Retentionist Countries, Death Penalty Info. Ctr. (Dec. 31, 2015), http://www.deathpenaltyinfo.org/abolitionist-and-reten tionist-countries?scid=30\&did=140 [https://perma.cc/F7LD-MT67] [hereinafter Abolitionist and Retentionist Countries, Death Penalty Info. Ctr.]. In addition, the death penalty is excluded from the punishments that the International Criminal Court may impose. (The International Criminal Court was established by a treaty in 1998). See Nora V. Demleitner, The Death Penalty in the United States: Following the European Lead?, 81 Or. L. Rev. 131, 143-144 (2002). Likewise, the International Criminal Tribunals for the former Yugoslavia and Rwanda, established by the United Nations Security Council, also excluded the death penalty. Id.

287. Kansas. v. Marsh, 548 U.S. 163, 199 (2006). See also Obergefell v. Hodges, 135 S. Ct. 2584, 2612 (2015) (Roberts, C.J., dissenting) (In discussing whether the Court should intervene in the debate over same sex marriage, Chief Justice Roberts stated in language that many would apply to a decision of the Court invalidating the death penalty "[i]t seizes for itself a question the Constitution leaves to the people, at a time when the people are engaged in a vibrant debate on that question."). 
Justice Scalia's argument is flawed in that it is difficult to imagine any issue that needs to be regulated by the Supreme Court more than the death penalty. First, there is the long history of racial discrimination in capital sentencing that continues to this day. ${ }^{288}$ Second, capital cases are often extremely emotional and may motivate vengeanceseeking behavior. It is often only the Court that is able to prevent mob rule and ensure a fair process in these emotionally-charged and often racially-tinged cases. Third, the defendants are an extremely unpopular minority who are not able to vindicate their rights through the political process, as the November 2016 vote in California rejecting abolition and supporting the "speeding up" of executions demonstrates. ${ }^{289}$ Finally, according to Chief Justice Marshall, the Court has a "virtually unflagging obligation" to exercise the jurisdiction bestowed upon them by Congress and the Constitution. ${ }^{290}$ The Eighth Amendment clearly mandates that the Court limit the types of punishment that the state can inflict upon individuals.

The final objection to the Court striking down the death penalty is to avoid a similar reaction when it found the death penalty as then applied to be unconstitutional in Furman. The Furman decision-striking down the death penalty - generated an enormous public backlash that unintentionally reinvigorated the death penalty, which had previously been on the decline. ${ }^{291}$ The decision mobilized the pro-death penalty movement into a political force for the first time. ${ }^{292}$ Within a few months of the decision, pro-death penalty activists campaigned in every state for reinstatement of the death penalty and were joined by police chiefs, state attorney generals, local district attorneys, and assorted politicians. ${ }^{293}$ Within two years of the decision, thirty-five states had enacted new capital statutes. ${ }^{294}$ The Supreme Court responded to the backlash by reinstating the death penalty four years later. ${ }^{295}$

288. See generally Steiker \& Steiker, supra note 27.

289. See Jazmine Ulloa \& Julie Westfall, California voters approve an effort to speed up the death penalty with Prop. 66, L.A. Times (Nov. 22, 2016), http://www.latimes.com/ politics/essential/la-pol-ca-essential-politics-updates-proposition-66-death-penalty-passes1479869920-htmlstory.html [https://perma.cc/FRY9-72S7].

290. Stephen I. Vladeck, Why an aggressive Supreme Court is good for the separation of powers, WASH. Times (July 6, 2015) http://www.washingtontimes.com/news/2015/jul/ 6/celebrate-liberty-month-why-an-aggressive-supreme-/?page=all [https://perma.cc/435MWMAP].

291. See David Garland, Peculiar Institution 230-34 (2010).

292. Id.

293. Id. at 232.

294. Id. at 233.

295. Gregg v. Georgia, 428 U.S. 153, 169 (1976). 
Several factors suggest that the current Court would not face a similar backlash should it find the death penalty unconstitutional. First, prior to Furman, the Court had not issued any decisions regulating the death penalty. States had largely unfettered latitude in carrying out the death penalty. Since 1976, the Court has placed important limitations on capital punishment. ${ }^{296}$ Therefore, the doctrinal framework is in place for the Court to strike down the death penalty. Furthermore, several members of the Court, both past and present, have been publicly critical of the death penalty ${ }^{297}$ and alerted the public to the problems in the administration of the death penalty. Thus, a decision invalidating capital punishment would not be totally unexpected as it had been when the Court issued its holding in Furman.

Second, the politics of the death penalty have substantially changed. During the 1988 presidential campaign, Michael Dukakis' opposition to the death penalty was a major campaign issue. ${ }^{298}$ By 2004, the politics of the issue had changed enough that the democratic nominee, John Kerry, was opposed to the death penalty, but his opposition did not make the death penalty a major issue in that campaign. ${ }^{299} \mathrm{~A}$ good example of the reaction the Court may anticipate if it invalidated the death penalty occurred during the 2008 presidential campaign. In the summer of 2008, during the heart of the presidential campaign, the Court issued its decision invalidating the death pen-

296. For instance, the Court has held that juveniles and the intellectually disabled cannot be executed, see Roper v. Simmons, 543 U.S. 551 (2005) and Atkins v. Virginia, 536 U.S. 304, 321 (2002); that the death penalty cannot be meted out for crimes do not involve the taking of human life, see Coker v. Georgia, 433 U.S. 584, 600 (1977) and Kennedy v. Louisiana, 554 U.S. 407, 413 (2008); that capital defendants have a right to be sentenced by juries, see Ring v. Arizona, 536 U.S. 584, 609 (2002); and that the defendant has wide latitude in offering mitigating evidence to save his life, see Tennard v. Dretke, 542 U.S. 274, 285 (2004).

297. See, e.g., Ring, 536 U.S. at 614-19 (Breyer, J., concurring) (discussing defects in prevailing capital practice); Kansas v. Marsh, 548 U.S. 163, 207-10 (2006) (Souter, J., dissenting) (arguing for a new capital jurisprudence in light of evidence of wrongful convictions); Baze v. Rees, 553 U.S. 35, 71 (2008) (Stevens, J., concurring) (questioning whether death penalty serves any useful social purpose); Callins v. Collins, 510 U.S. 1141, 1144 (1994) (Blackmun, J., dissenting) (announcing that he would no longer vote to allow an execution as a result of the Court's failed attempts to rectify problems in the administration of the death penalty).

298. See Samuel R. Gross \& Phoebe C. Ellsworth, Second Thoughts: Americans' Views on the Death Penalty at the Turn of the Century, in Beyond Repair? America's Death Penalty 7, 42-43 (Stephen P. Garvey ed., 2003).

299. See Robert Moran, Kerry's Death Penalty Dance, Nat'l Review (March 9, 2004), http://www.nationalreview.com/article/209815/kerry-s-death-penalty-dance-robert-moran [https://perma.cc/7UXW-ZM4J]. 
alty for rape of a child. ${ }^{300}$ Although both major presidential candidates disagreed with the decision, neither candidate made the decision an issue in the campaign. ${ }^{301}$ The reaction of opponents to the decision was brief and the discussion quickly moved on to other issues. In recent years, even candidates running for office in states that have abolished the death penalty have not made capital punishment a major campaign issue.

Third, the international community is significantly more interconnected than it was at the time of the Furman decision in 1972. The international reaction to a Supreme Court decision striking down the death penalty would likely be well received. Given the fact that most countries in the world have outlawed the death penalty, ${ }^{302}$ this decision would enhance the United States' international standing, and the favorable international reaction would likely have a similar downstream effect on American public opinion. Therefore, there is considerably less risk of public outcry today than there was in 1972 should the death penalty be struck down on constitutional grounds.

\section{Conclusion}

In 1963, Justice Goldberg wrote a dissent urging the Court to grant certiorari in order to decide whether the death penalty violated the Eighth Amendment. ${ }^{303} \mathrm{He}$ started a conversation which, nine years later, led to the Court determining that it did in fact violate the Constitution. Hopefully Justice Breyer's dissent has similarly started the much-needed conversation about whether the death penalty remains a constitutional practice. As this article has discussed, many of the problems that the Court believed would be eliminated-or at least minimized-when it began to regulate the death penalty have remained and, in some instances, been exacerbated: disparate racial application, arbitrariness, the risk of executing innocent individuals, the problem of ineffective assistance of counsel. The Court should allow these serious deficiencies to continue no longer. Almost every attempt to reform the death penalty has failed. Rather than continue the failed attempt to reform the death penalty, the Court needs to seri-

300. See Kennedy, 554 U.S. at 412-413.

301. See Linda Greenhouse, Justices Bar Death Penalty for the Rape of a Child, N.Y. Times (June 26, 2008), http://www.nytimes.com/2008/06/26/washington/26scotus .html?pagewanted=all [https://perma.cc/L9MD-9HP5].

302. See Abolitionist and Retentionist Countries, Death Penalty Info. Ctr., supra note 284.

303. See Rudolph v. Alabama, 375 U.S. 889 (1963) (Goldberg, J., dissenting from denial of certiorari). 
ously consider abolition as the only logical alternative. This article provides the doctrinal basis for doing so. 